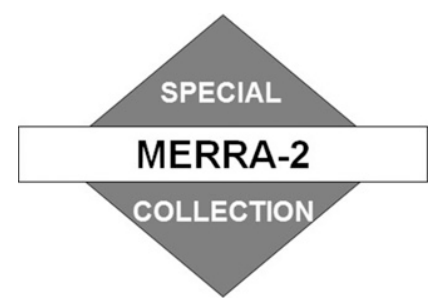

\title{
Accuracy Assessment of MERRA-2 and ERA-Interim Sea Surface Temperature, Air Temperature, and Humidity Profiles over the Atlantic Ocean Using AEROSE Measurements
}

\author{
Bingkun Luo, Peter J. Minnett, And Malgorzata SzczodraK \\ Rosenstiel School of Marine and Atmospheric Science, University of Miami, Miami, Florida \\ NiCHOLAS R. NALLI \\ IMSG, Inc. at National Oceanic and Atmospheric Administration/NESDIS/STAR, College Park, Maryland \\ VERNON R. MORRIS \\ NOAA Center for Atmospheric Sciences, Howard University, Washington, DC
}

(Manuscript received 18 December 2019, in final form 20 May 2020)

\begin{abstract}
Satellite and in situ measurements of the sea surface and the atmosphere often have inadequate sampling frequencies and often lack consistent global coverage. Because of such limitations, reanalysis model output is frequently used in atmospheric and oceanographic research endeavors to complement satellite and in situ data. The National Aeronautics and Space Administration's (NASA's) Goddard Earth Sciences Modern-Era Retrospective Analysis for Research and Applications version 2 (MERRA-2) and the European Centre for Medium-Range Weather Forecasts (ECMWF) interim reanalysis (ERA-Interim) datasets provide accurate, complete fields through the assimilation of many atmospheric and surface observations. Still, the reanalysis output data must be rigorously and continuously evaluated to understand their strengths and weaknesses. To this end, this study evaluates sea surface skin temperature ( $\mathrm{SST}_{\text {skin }}$ ) and atmospheric temperature and humidity profiles in MERRA-2 and ERAInterim data through comparisons with independent Marine-Atmospheric Emitted Radiance Interferometer (M-AERI) and radiosonde data from the Aerosols and Ocean Science Expeditions (AEROSE) cruises, focusing on the representation of spatial and temporal variability. $\mathrm{SST}_{\text {skin }}$ values are generally in good agreement with corresponding M-AERI measurements, with the average differences on the order of $0.1 \mathrm{~K}$. Comparisons between MERRA-2 and ERA-Interim relative humidity and air temperature profiles with a total of 553 radiosondes that have been withheld from data assimilation schemes show good correspondence below $500 \mathrm{hPa}$ : the average air temperature difference is $<2 \mathrm{~K}$ and the average relative humidity discrepancy is within $10 \%$. These results support the use of these MERRA-2 and ERA-Interim reanalysis fields in a variety of research applications.
\end{abstract}

\section{Introduction and motivation}

Atmospheric water vapor and temperature are fundamental variables of Earth's climate system. Profiles derived from various sources are crucial to weather and ocean forecasting and studying the climate system. The atmospheric water vapor and temperature over the subtropical Atlantic Ocean have high variability (Nalli et al. 2011; Szczodrak et al. 2007), and thus accurate knowledge of the distributions of these parameters is

\footnotetext{
Corresponding author: Bingkun Luo, 1bk@rsmas.miami.edu
}

important for understanding long-term climate change and, on shorter time scales, weather prediction (Hartmann 2002; Weckwerth et al. 1999). At the lower boundary, sea surface temperature (SST) is also one of the key parameters in climate variability and oceanographic research.

Dry layers over the tropical ocean are often observed (Kanitz et al. 2014; Szczodrak et al. 2014), and the water vapor vertical distribution effects on satellite remote sensing have been discussed by Barton (2011) and Minnett (1986). The atmospheric water vapor's temperature, which is nearly always colder than the SST, will significantly reduce the upwelling radiance, and 
thus introduce errors in satellite $\mathrm{SST}_{\text {skin }}$ retrievals. The temperature of the first 1-mm depth that can be measured by infrared radiometers is designated as $\mathrm{SST}_{\text {skin }}$ (Donlon et al. 2007; Minnett et al. 2001; Woodcock and Stommel 1947). Infrared radiative transfer simulations have been used to determine the water vapor concentration effect on the satellite-retrieved $\mathrm{SST}_{\text {skin }}$ (Minnett 1986; Szczodrak et al. 2014). A prominent example of anomalous atmospheric conditions is the Saharan mineral dust outflow, which is often associated with a dry layer, the Saharan air layer (SAL), which can extend thousands of kilometers over the Atlantic Ocean. The need to account for the effects of these dry layers has been recognized to accommodate further advances in numerical weather prediction (Pergaud et al. 2009) and to improve satellite remote sensing of the SST (Luo et al. 2020; Szczodrak et al. 2014). Typically, researchers use satellite as well as in situ measurements to analyze the SAL properties (Kanitz et al. 2014; Szczodrak et al. 2014). However, measurements taken from radiosondes are restricted in temporal and spatial coverage, and retrieval of the SAL and dust outflow properties, as well as quantifying their effects on $\mathrm{SST}_{\text {skin }}$ retrievals, presents a difficult challenge to satellite remote sensing. The low humidity values within the SAL and the sharp vertical gradients are not easy to retrieve from infrared or microwave satellite measurements (Nalli et al. 2016). Using data from the Cloud-Aerosol Lidar Infrared Pathfinder Satellite Observations (CALIPSO) lidar along with passive infrared and visible imagers, Adams et al. (2012) and Jordan et al. (2010) investigated the three-dimensional structure and characteristics of clouds and aerosol dust layers. CALIPSO makes nadir measurements, but spatial aerosol properties derived from visible and infrared imagers (Kaufman et al. 2002) at the time of a satellite overpass can be used to indicate those properties upwind or downwind; at other times an advection model can be used (Gehlot et al. 2015). Reanalysis procedures, which assimilate different kinds of satellite and in situ data, may result in accurate information about the atmosphere and sea surface for studying climate processes and predictability (Parker 2016). Additionally, the reanalysis fields of the sea surface and atmospheric variables are internally consistent, which can provide useful information for SAL and dust outflow research.

Over the past few decades, reanalysis datasets such as the European Centre for Medium-Range Weather Forecasts (ECMWF) reanalyses, ERA-Interim (Dee et al. 2011) and ERA-5 (Copernicus Climate Change Service Climate Data Store 2017), the National Centers for Environmental Predictions (NCEP)-National Center for Atmospheric Research (NCAR) reanalysis (Kalnay et al. 1996), the NCEP-Climate Forecast System Reanalysis (Saha et al. 2014), the National Aeronautics and Space Administration (NASA) Modern-Era Retrospective Analysis for Research and Applications (MERRA) (Rienecker et al. 2011), and the Japanese global atmospheric reanalysis JRA-55 (Kobayashi et al. 2015) have provided fields that can be used to propagate information from data-rich regions into sparse regions, thus providing input for various research. MERRA, released in 2009, was the first reanalysis product generated with the NASA Goddard Earth Observing System (GEOS) data assimilation system. The recently released MERRA-2 is the replacement of MERRA, taking advantage of improvements in data assimilation techniques (Gelaro et al. 2017).

The regular spatial grids and time steps of the reanalysis fields, and the wide selection of variables calculated to be internally consistent, render the reanalysis datasets very attractive and valuable resources for many research endeavors. The widespread application of these fields emphasizes the need to conduct studies to evaluate the accuracies and determine the uncertainty characteristics of the variables in the reanalysis fields. The assimilation of a very wide range of measurements, both in situ and remotely sensed, means the determination of the veracity of the reanalysis fields requires comparisons with independent data that have been withheld from the assimilation procedures.

In this study, we use in situ and remotely sensed ocean and atmospheric data collected during a series of Aerosol and Ocean Science Expedition (AEROSE) cruises (Morris et al. 2006; Nalli et al. 2011) onboard the NOAA ship Ronald H. Brown and the R/V Alliance to perform an assessment of MERRA-2 and ERA-Interim $\mathrm{SST}_{\text {skin }}$ values and atmospheric temperature and relative humidity profiles. The AEROSE data have been intentionally withheld from real-time data streams that are used as input to weather forecast models and subsequent reanalysis schemes and so are valuable for assessment of the accuracy of the reanalysis fields.

MERRA-2 and ERA-Interim datasets contain global oceanic and atmospheric variables, including SST as a variable that has been input to the reanalyses, as well as derived aerosol optical depth (AOD), air temperature, and water vapor, and therefore they have the potential to support many essential research activities directed at improving our knowledge of ocean-atmosphere interactions, the hydrological cycle, and the climate system. Several studies have investigated the performance of MERRA-2 and ERA-Interim fields for a variety of applications. Some of the uncertainties result from systematic dependences such as inaccuracies in input measurements, residual diagnosis uncertainties, and imperfections of atmospheric transmittance simulations 
and of processing algorithms. Guan et al. (2018) used in situ airborne dropsonde observations to validate the MERRA-2 and ERA-Interim total water vapor transport; they pointed out that the reanalysis fields could characterize atmospheric rivers. Randles et al. (2017) and Buchard et al. (2017) evaluated MERRA-2 AOD data by comparisons with independent values from ground-based, airborne, and ship-based measurements. They found MERRA-2 values correlated well with the observed AODs from the airborne Spectrometer for Sky-Scanning, Sun-Tracking Atmospheric Research (4STAR) programs. Robertson et al. (2016) used the rotated principal component analysis (RPCA) method to correct MERRA-2 atmospheric moisture transport. ERA-Interim middle tropospheric humidity profiles were also evaluated by Vergados et al. (2014) using global positioning system radio occultation (GPSRO) measurements in cloudy conditions from August 2006 to October 2006. Blending GPSRO with ERA-Interim produces temperature profiles in the lower troposphere with a bias of $\pm 1.0 \mathrm{~K}$ compared to radiosonde measurements; relative humidity profiles were produced with a bias from $\pm 3 \%$ to $\pm 10 \%$ with radiosondes according to latitude. ERA-Interim atmospheric temperature low-frequency variability and trends from 1979 to 2012 were examined by Simmons et al. (2014), and ERA-Interim correlated well with radiosonde measurements. Although many parameters of MERRA-2 and ERA-Interim have shown good agreement in previous investigations, a thorough assessment of atmospheric conditions over the Atlantic Ocean with the independent measurements used here has not been undertaken.

This paper presents the comparison of the MERRA-2 and ERA-Interim $\mathrm{SST}_{\text {skin }}$, and atmospheric profiles of air temperature and relative humidity with independent Marine Atmosphere Emitted Radiance Interferometer

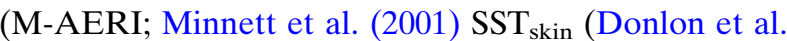
2007) measurements and atmospheric profiles measured by radiosondes. This paper is organized as follows: first, we introduce the MERRA-2 and ERA-Interim data followed by an overview of measurements from the AEROSE cruises in section 2. M-AERI SST skin $_{\text {mea- }}$ surements and the results of the comparisons are discussed in section 3 . Section 4 gives the estimations of the errors in vertical air temperature and relative humidity data from MERRA-2 and ERA-Interim, and collocated balloon-borne radiosonde observations. The relative humidity differences in various regions of the tropical Atlantic Ocean are also addressed in this section. A case study based on the inspection of individual SAL profiles is presented in section 5. Section 6 includes a discussion and summary of the results.

\section{Instruments and data}

\section{a. MERRA-2 reanalysis}

The MERRA-2 reanalysis model output was generated using the GEOS by NASA's Global Modeling and Assimilation Office Data Assimilation System version 5.12.4, covering the period of satellite Earth observation from 1980 to the present. MERRA-2 is downloaded through the Goddard Earth Sciences Data and Information Services Center (GES DISC) at http://disc.sci.gsfc.nasa.gov/ mdisc/. The MERRA-2 datasets contain geolocated, derived geophysical variables, including air temperature and humidity on a fixed pressure grid consisting of 42 standard pressure levels from a $1000-\mathrm{hPa}$ surface pressure to the model top of $0.1 \mathrm{hPa}$ (Buchard et al. 2017; Gelaro et al. 2017; Randles et al. 2017). The spatial resolution of MERRA-2 is $0.625^{\circ} \times 0.5^{\circ}$ in longitude and latitude. Before 2006, the Reynolds SST (Reynolds et al. 2007) and Taylor SST $1^{\circ}$ fields (Taylor et al. 2000) were used as the source for MERRA-2 boundary conditions on a weekly basis (Bosilovich et al. 2015) because they could provide continuous, global, gridded SST input. Since April 2006, MERRA-2 SST skin $_{\text {fields are produced }}$ from daily $0.05^{\circ}$ resolution SST from the Operational Sea Surface Temperature and Sea Ice Analysis (OSTIA) system as described by Donlon et al. (2012). Note that the $\mathrm{SST}_{\text {skin }}$ seasonal cycles are different in MERRA-2 and OSTIA, because OSTIA is an estimate of the foundation temperature (Donlon et al. 2007), in which diurnal heating and cooling signals are excluded. The steps of processing OSTIA into the MERRA-2 unified gridded $\mathrm{SST}_{\text {skin }}$ set have been discussed by Bosilovich et al. (2015) and Gelaro et al. (2017). The SST skin $_{\text {fields }}$ used in this study have 1-h temporal resolution and the atmospheric temperature and relative humidity profiles have 3-h temporal resolution.

MERRA-2 is the improved version of MERRA and assimilates more satellite data, including the CrossTrack Infrared Sounder (CrIS) and Advanced Technology Microwave Sounder (ATMS) onboard the Suomi-NPP satellite (Han et al. 2013; Kim et al. 2014); the Spinning Enhanced Visible and InfraRed Imager (SEVIRI; Aminou 2002) onboard the MeteoSat geostationary satellite; and other sensors. The improvements in MERRA-2 input data are described by McCarty et al. (2016). Some significant outcomes of the improvements have also been discussed by Bosilovich et al. (2017). The first major improvement for atmospheric water balance is how to handle the water vapor increments (Takacs et al. 2016), from which the atmospheric dry-air mass is conserved and the net source of water from precipitation and surface evaporation equals the total atmospheric water changes. 
2007

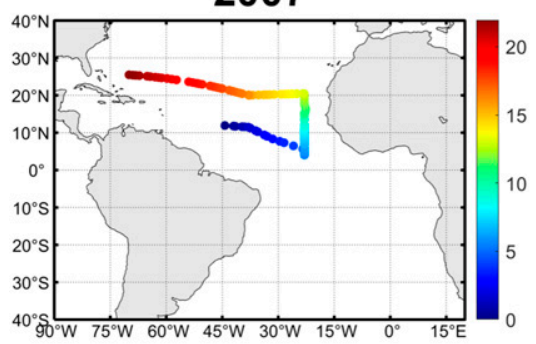

2011

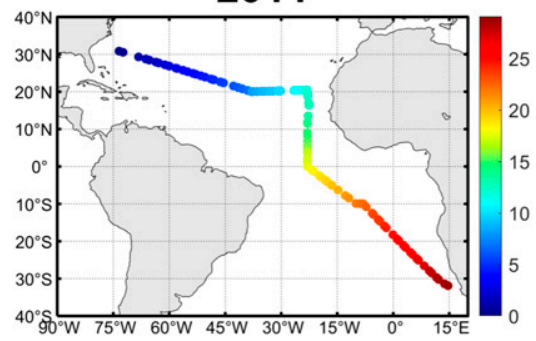

2008

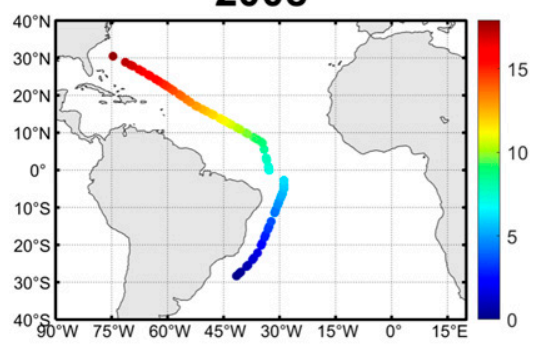

2013

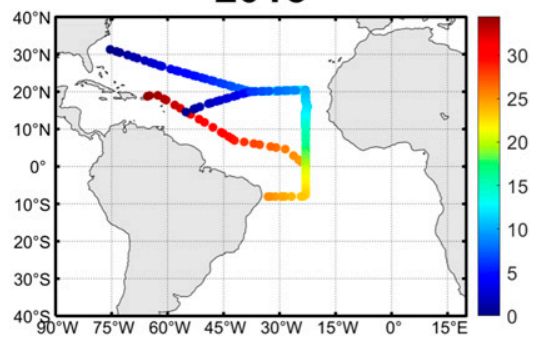

2009

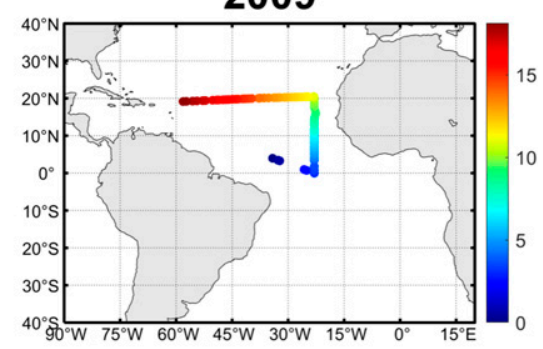

2015

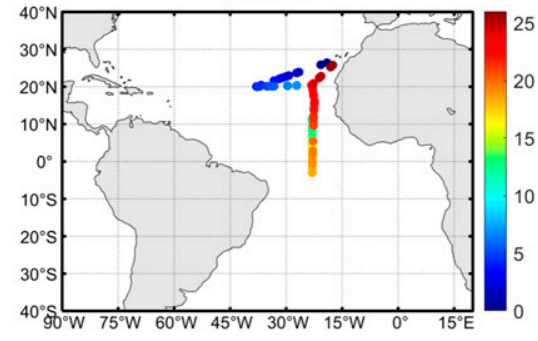

FIG. 1. Cruise tracks of the NOAA ship Ronald H. Brown, 2007-13, and R/V Alliance, 2015. The colors indicate the days since departure.

\section{b. ERA-Interim reanalysis}

The ECMWF global reanalysis dataset ERA-Interim contains sea surface and atmospheric products, including vertical temperature and humidity profiles with horizontal spatial resolution of $0.75^{\circ} \times 0.75^{\circ}$ and at 60 vertical pressure layers from the surface to $0.1 \mathrm{hPa}$ (Dee et al. 2011). The pressure levels of the ERA-Interim atmospheric variables are available at http://apps.ecmwf.int/ datasets/data/interim-full-daily/levtype $=\mathrm{pl} /$. The four daily analyses at 0000, 0600, 1200, and 1800 UTC are obtained by four-dimensional variational (4D-VAR) analysis systems (Courtier et al. 1994; Simmons et al. 1999). The MERRA-2 and ERA-Interim data used here for assessments are limited to AEROSE campaign periods, given below. As with MERRA-2, starting from February 2009, ERA-Interim data use OSTIA as an SST input field. An overview of different versions of ECMWF current and past reanalysis datasets is available from https://www.ecmwf.int/en/forecasts/datasets/browsereanalysis-datasets. For this paper, all of the ECMWF data are from ERA-Interim.

\section{c. AEROSE field campaigns}

The AEROSE research projects are on board the NOAA ship Ronald H. Brown or the R/V Alliance from 2004 to the present. Here we focus on cruises beginning in 2007 that have both M-AERI and radiosondes measurements. The SST and water vapor retrievals from satellite instruments can be quantified with the AEROSE data (Nalli et al. 2006, 2011). A M-AERI was aboard the AEROSE ships to take measurements of the sea surface and atmosphere emitted radiance. These measurements are used to derive estimates of SST $_{\text {skin, }}$ which can be used to characterize the accuracy of MERRA-2 and ERA-Interim SST $_{\text {skin. }}$ Balloon-borne radiosondes were launched from the ships every $4-8 \mathrm{~h}$ and are used here to assess the accuracy of the atmospheric temperature and relative humidity profiles of MERRA-2 and ERAInterim datasets. The ships' tracks of the AEROSE expeditions considered here are shown in Fig. 1, where the colors indicate the days since departure. The AEROSE campaigns datasets were acquired during May 2007, May 2008, July-August 2009, July-August 2011, JanuaryFebruary 2013, and November-December 2015. Most of these cruises also served to refurbish the moorings of the Prediction and Research Moored Array in the Tropical Atlantic (PIRATA) array (Bourlès et al.2019), especially those forming the Northeast Extension along $24^{\circ} \mathrm{W}$ (Foltz et al. 2018).

The Saharan dust outbreaks have been detected during AEROSE campaigns from Microtops sun photometer AOD measurements along with radiosondes launched from the ships. The SALs are generally associated with dry air aloft and readily identified in radiosonde measurements as dry layers overlying a low-level boundary layer inversion. The data acquired by AEROSE project provide opportunities for validating MERRA-2 and ERA-Interim atmospheric profiles.

\section{d. $M-A E R I$}

This study uses the in situ $\mathrm{SST}_{\text {skin }}$ data from M-AERI (Fig. 2), a ship-based radiometer (Minnett et al. 2001) installed above the sea surface on various ships. M-AERI 


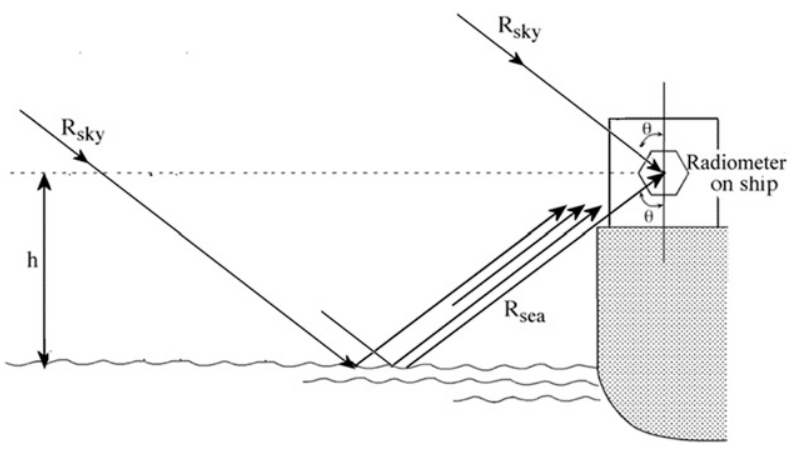

FIG. 2. M-AERI viewing geometry.

use two blackbodies and two infrared detectors to calibrate and obtain the sea surface emitted spectras. The viewing geometry from nadir to zenith to the detectors is shown in Fig. 2. After the interferometer measures the oceanic and atmospheric emission over a specific period and gets the desired signals over the level of background noise, the scan mirror rotates to take measurements of the blackbody targets' emission to perform the calibration. The technical details are given by Minnett et al. (2001), and although the M-AERIs used in this study are of a more recent design, their principle of operation is the same as the first versions. The M-AERI installation onboard the Ronald H. Brown is shown in Fig. 3. The spectral radiance obtained by M-AERI is useful to deriving various geophysical parameters such as $\mathrm{SST}_{\text {skin }}$ and near-surface air temperate.

\section{e. Ship-launched radiosonde profiles}

Measurements of vertical atmospheric temperature and relative humidity profiles using Vaisala RS92 radiosondes were obtained every $4-8 \mathrm{~h}$ throughout the
AEROSE campaigns. The AEROSE quality-controlled radiosondes have not been assimilated into any numerical weather prediction (NWP) or reanalysis schemes and can be treated as independent data (Nalli et al. 2011, 2013).

Several sources of Vaisala radiosonde inaccuracies have been identified (Divakarla et al. 2006; Miloshevich et al. 2004). For example, inaccuracies in the calibration model, including curve-fit error, have introduced some dry biases in the radiosonde measurements. From the Vaisala RS92 radiosonde data processing scheme (Dirksen et al. 2014), the relative humidity alone is not a reliable proxy for the presence of ice clouds. Miloshevich et al. (2006) provide a thorough discussion on the use of saturation pressure over water and over ice: the RS92 radiosonde equation for saturation water vapor pressure is calculated as by Hyland and Wexter (1983) over ice and Wexler (1976) over liquid water. If the RS92 mirror temperature is below $-10^{\circ} \mathrm{C}$, the relative humidity "phase ambiguity error" discussed by Miloshevich et al. (2006) can be as large as $10.3 \%-34.3 \%$ depending on the mirror temperature. Besides, a coating of ice on the sensor might limit the humidity of the air that reaches the sensor and cause a contamination bias to the measurement. The radiosonde inaccuracies (Vömel et al. 2007) must be kept in mind when using the measurements as references, as is done in this study. Radiosondes take measurements every second, which results in a very high vertical resolution $(\sim 0.1 \mathrm{hPa})$ depending on the speed of ascent. MERRA-2 and ERA-Interim resolve the vertical atmospheric structure in 42 layers and 60 layers, so we interpolate the vertical resolution of the radiosonde data to match the reanalysis fields, selecting the radiosonde measurements in thin layers having a pressure

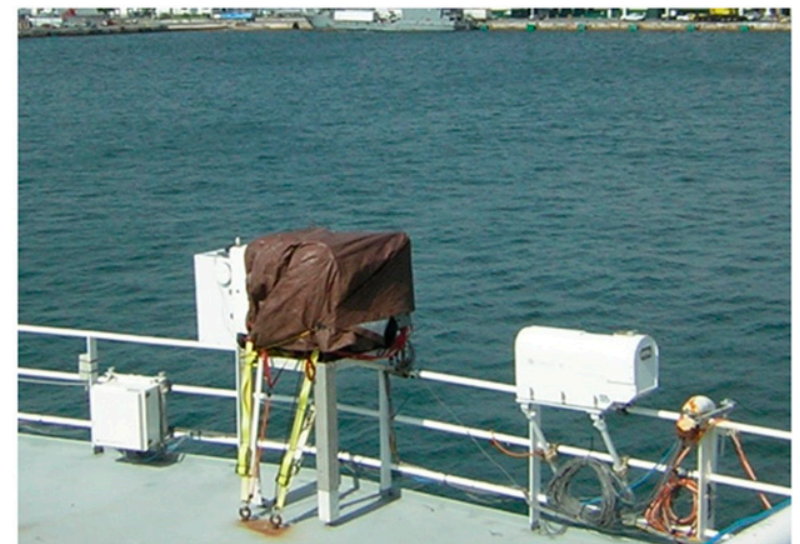

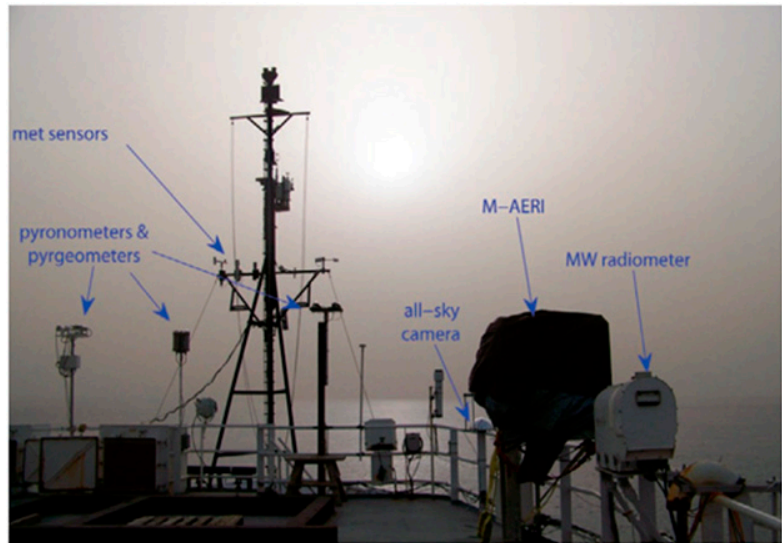

FIG. 3. (left) Unenhanced photograph of the forward of the NOAA research vessel Ronald H. Brown, taken during AEROSE-III, on the afternoon of 13 May 2007, when there is a strong Saharan dust aerosol outflow pulse (Nalli et al. 2011). (right) The M-AERI is mounted on the starboard side railing of the $\mathrm{O} 2$ deck of the ship. 
difference $<1 \mathrm{hPa}$ against the reanalysis data. As we know, ascending radiosondes drift horizontally due to winds. As given earlier, the reanalysis data are on a $0.5^{\circ}$ longitude $\times 0.625^{\circ}$ latitude horizontal grid for MERRA-2 and $0.75^{\circ} \times 0.75^{\circ}$ for ERA-Interim. Ascending radiosondes will be displaced in the horizontal relative to the launch position (McGrath et al. 2006). We collocate the reanalysis data with the radiosonde GPS location information of each level in our study. A total of 553 radiosondes over the tropical and subtropical Atlantic Ocean deployed during the AEROSE cruises are used here.

Relative humidity is calculated using the saturated water vapor pressure. The Vaisala RS92 sensor relative humidity algorithm assumes that the saturated water vapor pressure is set against liquid water even for conditions where ice particles coexist below the freezing point. However, the MERRA-2 and ERA-Interim relative humidity algorithms employed a modified version of Teten's formula (Simmons et al. 1999) in which the saturated water vapor pressure over ice is calculated in conditions where the ambient temperature is below the freezing point, as will be discussed in section 4 . We only assess how well the reanalysis profiles below $500 \mathrm{hPa}$ agree with radiosonde data in this study.

\section{3. $\mathbf{S S T}_{\text {skin }}$ accuracy assessment}

Satellite-based and M-AERI ship-based radiometric measurements provide the data to derive $\mathrm{SST}_{\text {skin }}$. During the day, the temperature of the near-surface layer is influenced by the absorption of solar radiation, and during both day and night, the ocean loses heat to the atmosphere, thus cooling the surface layer. The diurnal warming effect may be affected by surface wind, by cloud amount and type, by free convection, or by internal waves (Gentemann et al. 2003). The Group for High Resolution SST (GHRSST) Science Team has given the definitions of various SST during the day or at night (Donlon et al. 2007).

The ocean skin temperature results from the turbulent and net longwave radiative heat loss to the atmosphere, as discussed by Fairall et al. (1996), Minnett (2003), Wong and Minnett (2018), and others. MERRA-2 and ERA-Interim SST $_{\text {skin }}$ schemes have included three different near-surface ocean effects: the cool skin, the diurnal warm layer, and the salinity effects on the saturation specific humidity on the air side of the surface. Details of these three different layer parameterizations have been given in Zeng and Beljaars (2005), ECMWF (2016), and Akella et al. (2017).

For the reasons given earlier, the M-AERI is very suitable for validating the reanalysis $\mathrm{SST}_{\text {skin }}$ datasets.
For the comparisons between the M-AERI SST $_{\text {skin }}$ measurements and reanalysis products, the MERRA-2 and ERA-Interim gridded $\mathrm{SST}_{\text {skin }}$ fields were bilinearly interpolated in space and linearly interpolated in time to the M-AERI positions and measurement times. Figure 4 shows the time series of M-AERI, MERRA-2, and ERA-Interim $\mathrm{SST}_{\text {skin }}$ during the AEROSE cruises. All three datasets show pronounced variability according to the location and season of the cruises. The comparisons between MERRA-2, ERA-Interim and in situ M-AERI $\mathrm{SST}_{\text {skin }}$ data reveal good qualitative agreement in capturing the large-scale $\mathrm{SST}_{\text {skin }}$ features and gradients.

Tables 1 and 2 summarize the statistics of the differences between reanalysis $\mathrm{SST}_{\text {skin }}$ and M-AERI SST $\mathrm{Skin}_{\text {sin }}$. The cool ocean skin is the result of heat loss to the atmosphere near the water surface; the cool skin effects have been incorporated in both daytime and nighttime for MERRA-2 and ERA-Interim. However, daytime solar heating and nighttime heat loss lead to different surface diurnal layers (Gentemann et al. 2003; Minnett 2003). We separate daytime and nighttime $\mathrm{SST}_{\text {skin }}$ differences for each reanalysis to allow the impact of the diurnal cycle to be considered. The reanalysis $\mathrm{SST}_{\text {skin }}$ values are slightly higher than M-AERI SST $_{\text {skin. The }}$ MERRA- 2 mean difference is $0.085 \mathrm{~K}$ during the day and $0.098 \mathrm{~K}$ during the night, while the ERA-Interim difference has mean values of $0.123 \mathrm{~K}$ during the day and $0.142 \mathrm{~K}$ at night. During 2015, the average $\mathrm{SST}_{\text {skin }}$ difference is $\sim 0.01 \mathrm{~K}$, the standard deviation (STD) is $\sim 0.3 \mathrm{~K}$, and the root-mean-square (RMS) is $\sim 0.3 \mathrm{~K}$, which shows the best correspondence between M-AERI and reanalysis data. The 2007 data have relatively large STD, $\sim 0.4 \mathrm{~K}$ for MERRA-2 and $\sim 0.6 \mathrm{~K}$ for ERA-Interim, as well as large RMS, $\sim 0.41-0.48 \mathrm{~K}$ for MERRA-2 and $\sim 0.62-0.69 \mathrm{~K}$ for ERA-Interim.

Plots of the MERRA-2 and ERA-Interim SST skin $_{\text {with }}$

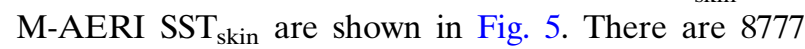
match-ups during the day, and 8977 at night. The correlation coefficient $R$ between M-AERI and MERRA-2 $\mathrm{SST}_{\text {skin }}$ is 0.989 and between M-AERI and ERA-Interim $\mathrm{SST}_{\text {skin }}$ is 0.981 . Extreme outliers were mostly noted during unusual atmospheric conditions. Furthermore, the comparisons require temporal and spatial interpolation, so the different spatial resolutions and temporal sampling of the reanalysis fields and M-AERI data are possible factors in the $\mathrm{SST}_{\text {skin }}$ differences.

Plotted in Fig. 6 are the SST skin $_{\text {differences between }}$ MERRA-2 (top) and ERA-Interim (bottom) along the cruise tracks. The two reanalysis $\mathrm{SST}_{\text {skin }}$ fields capture the $\mathrm{SST}_{\text {skin }}$ features along the ships' tracks very well, although the M-AERI SST skin $_{\text {values are systematically }}$ colder. The cause of the negative differences near the Saharan dust region is probably the result of aerosol 

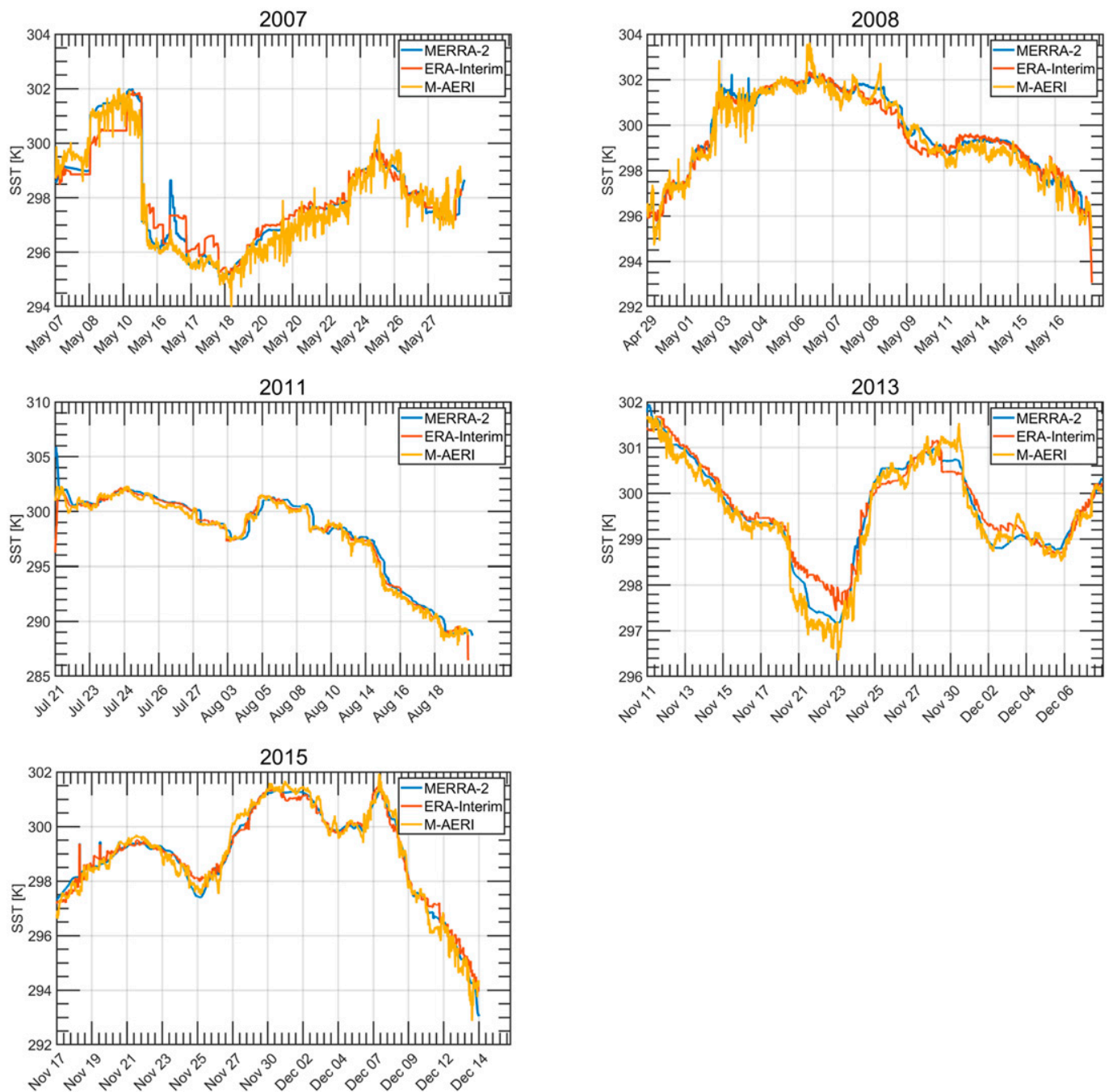

FIG. 4. Time series of MERRA-2 and ERA-Interim $\mathrm{SST}_{\text {skin }}$ and $\mathrm{SST}_{\text {skin }}$ derived by the M-AERIs onboard the research vessels Ronald H. Brown and Alliance. Blue, orange, and yellow lines correspond to MERRA-2 SST skin $_{\text {, }}$ ERA-Interim SST $_{\text {skin }}$, and M-AERI SST skin. $_{\text {. }}$

effects imperfectly represented in the models used to generate the reanalysis fields (Luo and Minnett 2020). The input data assimilated in MERRA-2 and ERAInterim in this region include satellite radiances from infrared measurements such as from SEVIRI and
NASA Earth Observing System (EOS) ModerateResolution Imaging Spectroradiometer (MODIS) (McCarty et al. 2016). When not accounted for, the aerosol layers' radiation effects generally lower the radiances measured by satellite infrared radiometers (Luo

TABLE 1. MERRA-2 SST $\mathrm{Skin}_{\text {sin }}$ min M-AERI SST $\mathrm{S}_{\text {skin }}$.

\begin{tabular}{|c|c|c|c|c|c|c|c|c|c|c|}
\hline \multirow[b]{2}{*}{ Year } & \multicolumn{5}{|c|}{ Day } & \multicolumn{5}{|c|}{ Night } \\
\hline & $N$ & Mean (K) & Median (K) & $\operatorname{STD}(\mathrm{K})$ & RMS (K) & $N$ & Mean (K) & Median (K) & STD (K) & RMS (K) \\
\hline 2007 & 568 & 0.032 & 0.103 & 0.411 & 0.412 & 678 & 0.186 & 0.178 & 0.447 & 0.484 \\
\hline 2008 & 782 & 0.224 & 0.276 & 0.474 & 0.524 & 784 & 0.201 & 0.207 & 0.428 & 0.473 \\
\hline 2011 & 1170 & 0.184 & 0.224 & 0.330 & 0.378 & 1096 & 0.155 & 0.177 & 0.310 & 0.347 \\
\hline 2013 & 3528 & 0.108 & 0.115 & 0.279 & 0.299 & 3574 & 0.112 & 0.132 & 0.204 & 0.233 \\
\hline 2015 & 2729 & -0.015 & -0.052 & 0.267 & 0.267 & 2845 & 0.015 & -0.031 & 0.308 & 0.309 \\
\hline Total & 8777 & 0.085 & 0.084 & 0.325 & 0.336 & 8977 & 0.098 & 0.098 & 0.301 & 0.316 \\
\hline
\end{tabular}


TABLE 2. ERA-Interim $S_{S T} T_{\text {skin }}$ minus M-AERI SST $T_{\text {skin. }}$.

\begin{tabular}{|c|c|c|c|c|c|c|c|c|c|c|}
\hline \multirow[b]{2}{*}{ Year } & \multicolumn{5}{|c|}{ Day } & \multicolumn{5}{|c|}{ Night } \\
\hline & $N$ & Mean (K) & Median (K) & STD (K) & RMS (K) & $N$ & Mean (K) & Median (K) & STD $(K)$ & RMS (K) \\
\hline 2007 & 568 & 0.048 & 0.190 & 0.625 & 0.626 & 678 & 0.266 & 0.313 & 0.637 & 0.690 \\
\hline 2008 & 782 & 0.106 & 0.219 & 0.644 & 0.653 & 784 & 0.096 & 0.173 & 0.629 & 0.636 \\
\hline 2011 & 1170 & 0.211 & 0.212 & 0.370 & 0.425 & 1096 & 0.116 & 0.193 & 0.610 & 0.621 \\
\hline 2013 & 3528 & 0.192 & 0.181 & 0.399 & 0.443 & 3574 & 0.197 & 0.177 & 0.350 & 0.402 \\
\hline 2015 & 2729 & 0.018 & -0.009 & 0.348 & 0.349 & 2845 & 0.067 & 0.027 & 0.345 & 0.352 \\
\hline Total & 8777 & 0.123 & 0.116 & 0.435 & 0.452 & 8977 & 0.142 & 0.149 & 0.445 & 0.471 \\
\hline
\end{tabular}

et al. 2019; Nalli and Stowe 2002). Otherwise, although having small mean differences and scatter when compared to M-AERI data, MERRA-2 and ERA-Interim each provide a good description of the $\mathrm{SST}_{\text {skin }}$ fields in this region.

\section{Atmospheric profile assessment}

The range of atmospheric conditions that were encountered during AEROSE as the ships crossed the tropical and subtropical Atlantic Ocean provides an opportunity to test the accuracies of the MERRA-2 and ERA-Interim profiles under a variety of meteorological conditions, including occasions of significant Saharan dust loading and SAL events. In the analysis that follows, radiosondes are taken as the reference to assess the accuracies of the reanalysis atmospheric fields of temperature and humidity. This is done with the knowledge that the radiosondes are not perfect and that the resulting statistics of the comparisons will contain a component that results from inaccuracies in the radiosonde measurements. A total of 96, 74, 78, 102, and 111 radiosondes were deployed from the NOAA ship Ronald H. Brown during 2007, 2008, 2009, 2011, and
2013 AEROSE cruises and 92 radiosondes from the R/V Alliance in 2015. Imperfections in the representation of cloud radiative effect and aerosol dust, along with all other atmospheric factors, play a role in reanalysis uncertainty (Gelaro et al. 2017; Randles et al. 2017). We have computed statistics using all the radiosondes from a total of 553 profiles.

In this study we assess how well the MERRA-2 and ERA-Interim datasets characterize the relative humidity and air temperature up to $500 \mathrm{hPa}$. As discussed by Simmons et al. (1999) and Clark and Harwood (2003), MERRA-2 and ERA-Interim operational 4D-VAR analysis systems use saturation vapor pressure for a temperature of $0^{\circ} \mathrm{C}$ over water and $-23^{\circ} \mathrm{C}$ over ice particles, with a mixed formula between them when necessary. And the "background" relative humidity values, the 6-h forecast data from the preceding analysis, have been used to derive the next forecast value. Above $300 \mathrm{hPa}$, the 3D-VAR resulted in a relatively low water vapor value; however, the 4D-VAR adopted Teten's formula to derive saturation vapor pressure, causing a significantly increased moistening effect on humidity above $300 \mathrm{hPa}$. The $4 \mathrm{D}-\mathrm{VAR}$ direct relative humidity
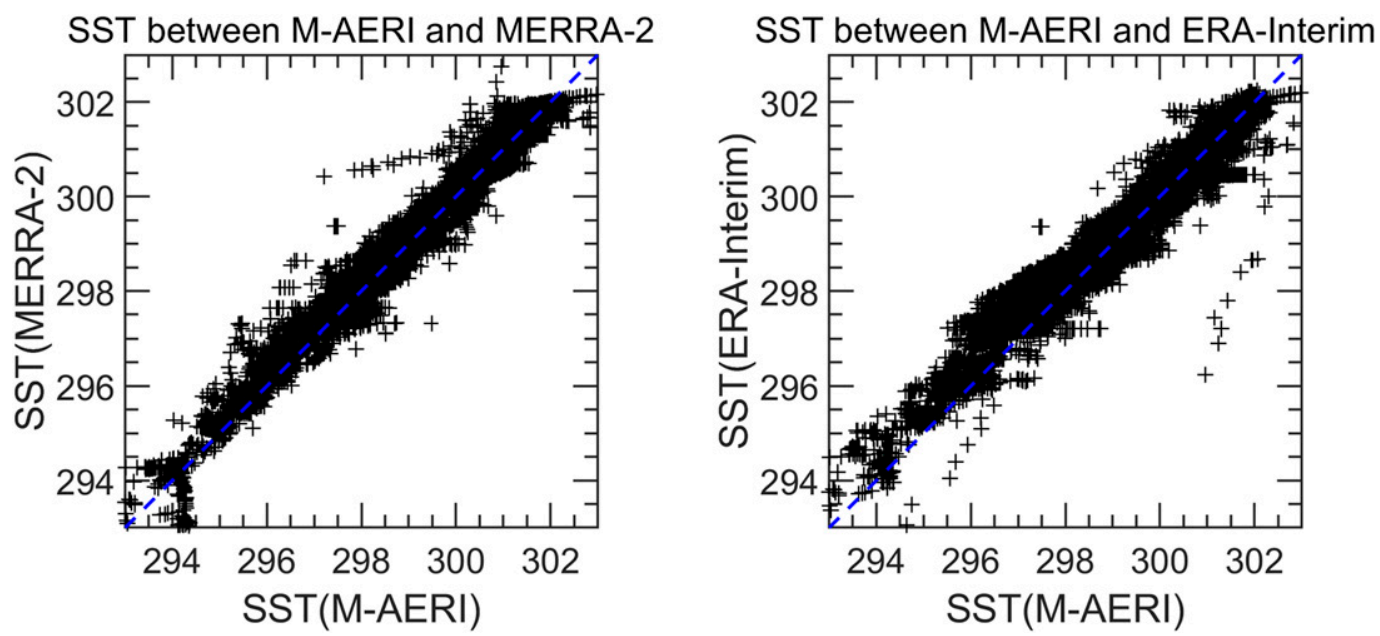

FIG. 5. Scatterplot of M-AERI SST ${ }_{\text {skin }}$ with (left) MERRA-2 SST $T_{\text {skin }}$ and (right) ERA-Interim SST $_{\text {skin }}$. Temperatures are in kelvins $(\mathrm{K})$. 


\section{MERRA2 minus M-AERI SST}

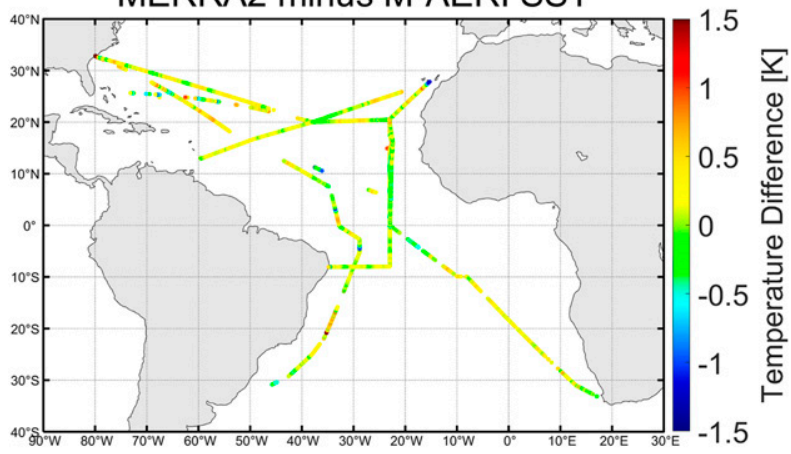

ERA-Interim minus M-AERI SST

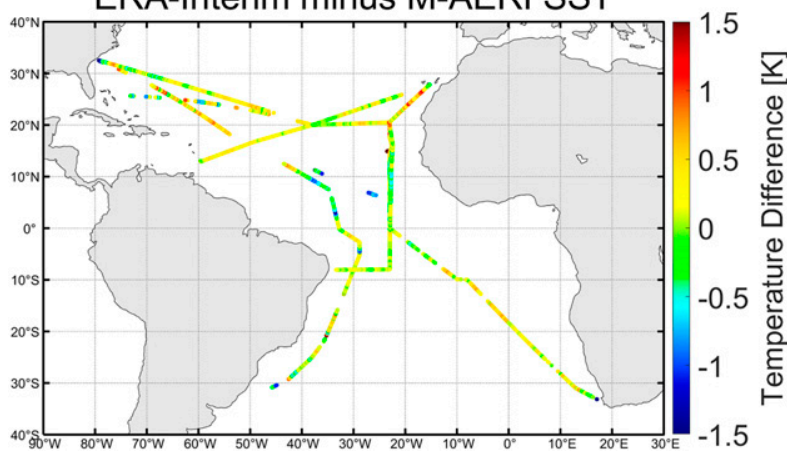

FIG. 6. Plot of $\mathrm{SST}_{\text {skin }}$ differences between (top) MERRA-2 and M-AERI and (bottom) ERA-Interim and M-AERI. Data gaps along the tracks mainly result from the M-AERI operation being suspended in rain or when sea spray reaches the instruments.

and temperature simulations from radiosondes are only below $300 \mathrm{hPa}$ and the radiosonde air temperature is almost always below the freezing point above $500 \mathrm{hPa}$; we limit our study to pressures $>500 \mathrm{hPa}$ to fairly assess the relative humidity of two reanalysis data in the lower troposphere.

\section{a. Temperature profile properties}

Figure 7 shows atmospheric temperature sections; the $x$ axis is the day of the year and the $y$ axis is the temperature sections along each AEROSE cruise track. At first glance, all datasets agree well, and both reanalyses capture the small-scale temperature variations due to dry layers or cloud, with the ERA-Interim reanalysis showing better consistency compared to radiosondes than MERRA-2. When an AEROSE campaign encountered aerosol dust layers, the warm air temperature disturbances due to the aerosol layer can be seen in Fig. 7 at $800-900 \mathrm{hPa}$ for days $132-137$ of 2007, 206-209 of 2009, and 210-217 of 2011. The air temperature fields in Fig. 7 show signals that can be explained by shortwave absorption warming through the vertical extent of the aerosol layer (Fig. 10). Caponi et al. (2017) argue that because of the relatively greater density, the absorption of solar radiation by desert dust aerosols can be comparable to that of black carbon aerosols. Thus, temperature anomalies in the $700-900-\mathrm{hPa}$ level during are seen in aerosol dust conditions. Both reanalyses have captured this significant temperature signature. However, as shown in Figs. 8 and 9, there are still inconsistent biases between radiosondes and reanalysis at the bottom of the dust layer. The results show that, in general, the MERRA-2 and ERA-Interim data qualitatively represent the spatial and temporal characteristics of atmospheric temperature very well.

The sections of the atmospheric temperature differences between the radiosonde measurements and the reanalysis fields of both the MERRA-2 and ERAInterim have similar patterns; Fig. 8 is for MERRA-2 and Fig. 9 is for ERA-Interim. In most cases, the atmospheric temperature difference remains $<2 \mathrm{~K}$. The differences between reanalysis and radiosonde data are usually negative below $500 \mathrm{hPa}$.

Large temperature differences between reanalyses and radiosondes often occur at the boundaries of the dry layers, as can be seen in Figs. 7, 8, and 9. These large differences are observed every time the MERRA-2 dust mixing ratio profiles indicate large scale Saharan dust outflow, on days 135-142 of 2007, 205-210 of 2009, 210 215 and 222-227 of 2011, and 325-333 of 2015, for example (Fig. 10; ERA-Interim dust profiles are similar but not shown). These discrepancies appear to be associated with the SAL boundary, and may be related to different spatial resolutions of reanalysis and radiosondes. Despite these localized differences, there is still good correspondence between reanalysis data and radiosonde measurements. Overall, the atmospheric temperatures in MERRA-2 and ERA-Interim fields compare well with independent radiosonde temperature data.

\section{b. Humidity profile properties}

In this area, atmospheric moisture plays a crucial role in the radiative forcing (Forster et al. 2007), water balance, and weather and climate (Bosilovich et al. 2017), and so correctly describing the distribution of water vapor is fundamental to many applications. As discussed in section 1 , the $3 \mathrm{D}$ distribution of relative humidity is difficult to measure both by satellite and traditional methods; however, reanalysis data may provide useful information, provided they are of good accuracy. Figure 11 shows relative humidity profiles collocated with radiosondes launched during the AEROSE cruises (left), MERRA-2 (center), and ERA-Interim (right). When compared to the radiosonde profiles the MERRA-2 and ERA-Interim data show the capability of both datasets 

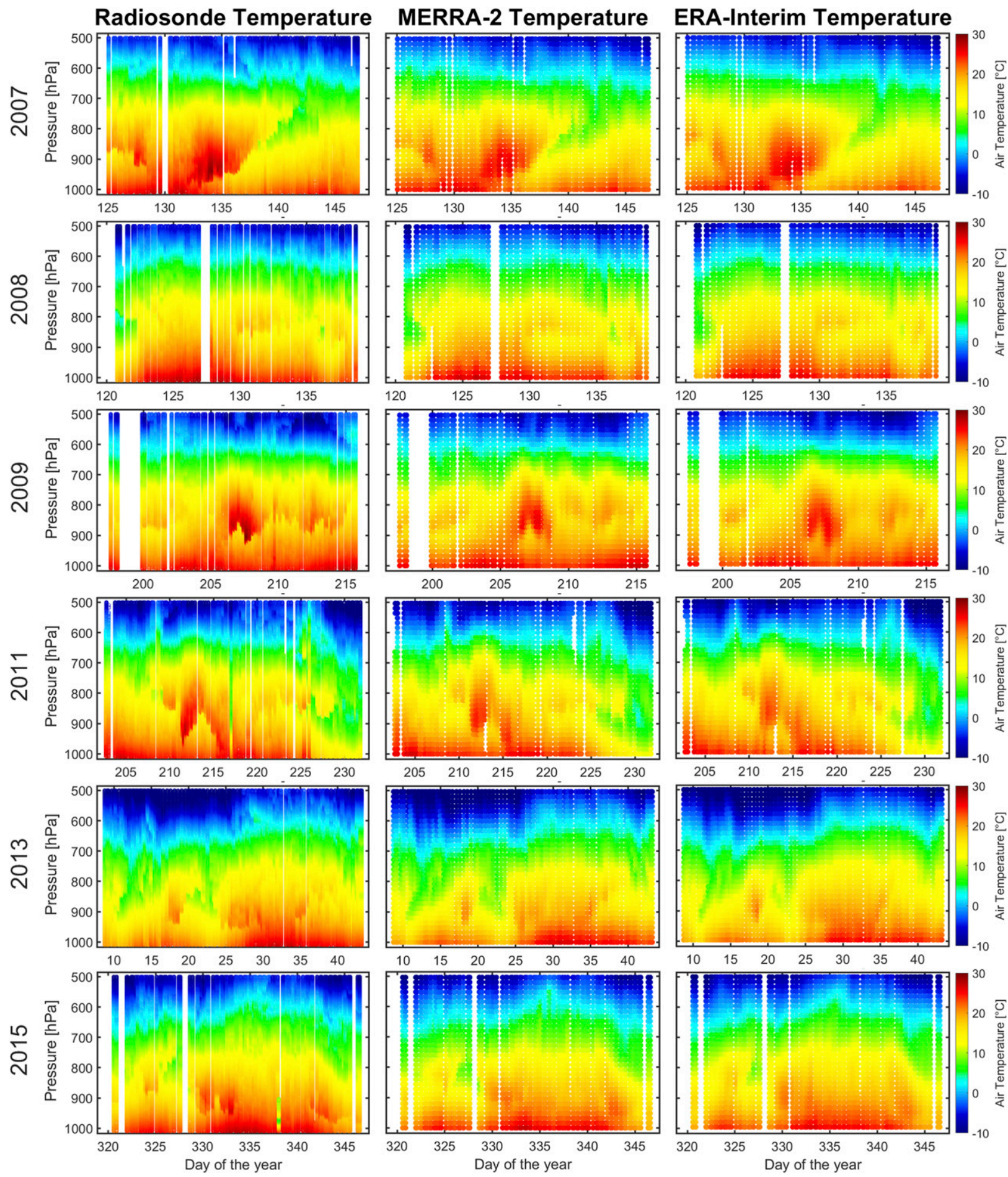

FIG. 7. Temperature sections from (left) radiosondes, (center) MERRA-2, and (right) ERA-Interim. The color indicates the air temperature.

to represent the spatial scales and temporal characteristics of relative humidity in this region. On the days when the R/V Ronald H. Brown entered significant, large-scale Saharan dust outflow events, shown in
Fig. 10, the dry layer is well represented by both MERRA-2 and ERA-Interim profiles (Fig. 11). Between approximately days 328-332 and 340-345 of 2015 , the radiosonde data show a layer of warm, dry air 



FIG. 8. Temperature differences between AEROSE radiosondes and MERRA-2 along the AEROSE cruise tracks. Color indicates temperature difference as shown at right.

just above a moist marine boundary layer. Also, in days $132-143$ of 2007 there was a very strong dry layer signal. Specifically, 13 May (day 133 of 2017) is when the photo in Fig. 3 was taken. It is clear that MERRA-2 and ERAInterim agree well with the radiosonde data and can capture the significant atmospheric features present during AEROSE cruises.

The relative humidity differences between reanalysis and radiosonde data (Figs. 12 and 13 ) reveal that the MERRA-2 fields are moister than those of the ERAInterim and both reanalysis products are moister than the radiosonde measurements. Reanalysis products do not replicate the humidity profiles at high altitude (500$600 \mathrm{hPa}$ ) as there are likely to be ice particles when the air temperature is below the freezing point. One possible contributor to this discrepancy could be inaccuracies in the radiosonde measurements themselves, as they can have biases at high altitude perhaps caused by ice on the sensor; also, the saturation water vapor pressure over ice or over liquid water is different in the radiosonde data processing scheme than in the reanalysis code. Some differences between MERRA-2 and radiosonde relative humidity, shown in Fig. 12, are as large as $\Delta \mathrm{RH}=+60 \%$ near the edge of dust layer. We are unaware of physical explanations for such high relative humidity at this level. It is noteworthy that Kennedy et al. (2011) report that the MERRA fields exhibit a similar significant bias at high altitudes based on Atmospheric Radiation Measurement (ARM) Program radar-lidar measurements. The reason for this is also likely to be in part due to the lack of in situ radiosonde data available for assimilation to the reanalysis models (Nalli et al. 2006).

In summary, the comparisons between MERRA-2 and ERA-Interim data and measurements from 553 radiosondes 

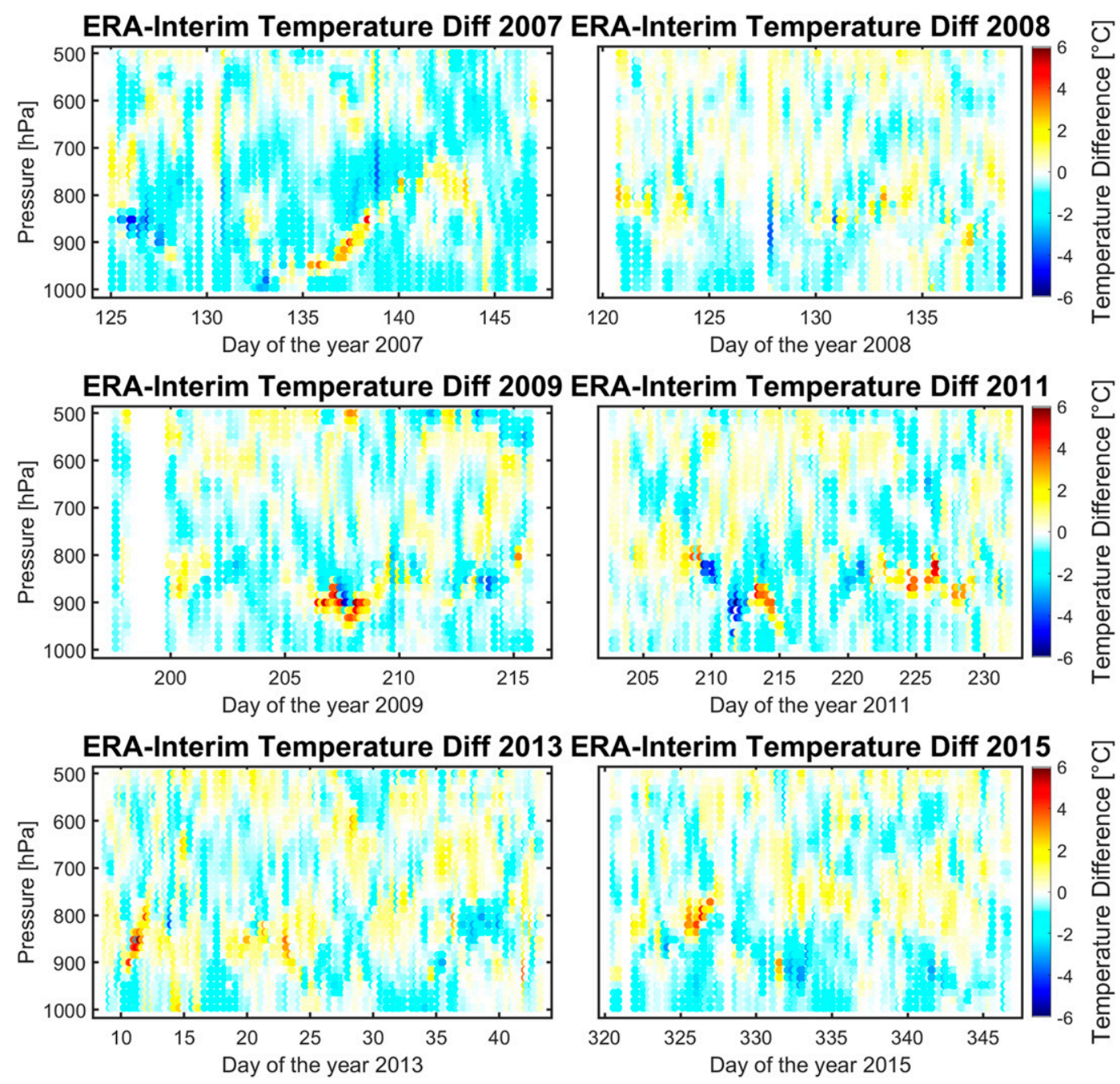

FIG. 9. As in Fig. 8, but for ERA-Interim reanalyses.

acquired during the AEROSE field campaigns between May 2007 and December 2015, show good quantitative agreement. The averaged relative humidity differences according to deployment locations and vertical pressure layers as shown in Fig. 14 are within 10\%.

\section{c. Distribution of relative humidity differences}

How well MERRA-2 and ERA-Interim fields represent the atmospheric variability and the suitability of these datasets for application to climate research has been shown above, so now we highlight the distributions of their differences. To examine the spatial consistency of the relative humidity differences between reanalysis and radiosonde, we divided the radiosonde launch locations into four areas bounded with different colors in Fig. 14 (top). The lower panels in the figure show the vertical distributions of the differences, color-coded to match the different areas.
For the Saharan outflow region, the area in the eastern Atlantic Ocean, shown by the blue box in Fig. 14, the average MERRA-2 and ERA-Interim differences (solid lines) below $900 \mathrm{hPa}$ are small compared to other regions, but the range of differences (blue shading) is large in the lower troposphere. This significant difference range is likely related to the presence of the dry layer aloft and the failure to represent properly the dry layer or inaccurate representation of their vertical locations. Compared to ERA-Interim, MERRA-2 has a larger positive difference at higher altitudes and near the lower boundary of the dry layer $(\sim 900 \mathrm{hPa})$. This result is consistent with those of Kennedy et al. (2011). Areas to the west and south, delineated by red and green boxes in Fig. 14, are also frequently under the influence of the Saharan dust outflows with the southern area including the intertropical convergence zone (ITCZ), which marks the southern extent of the SAL (Marticorena 

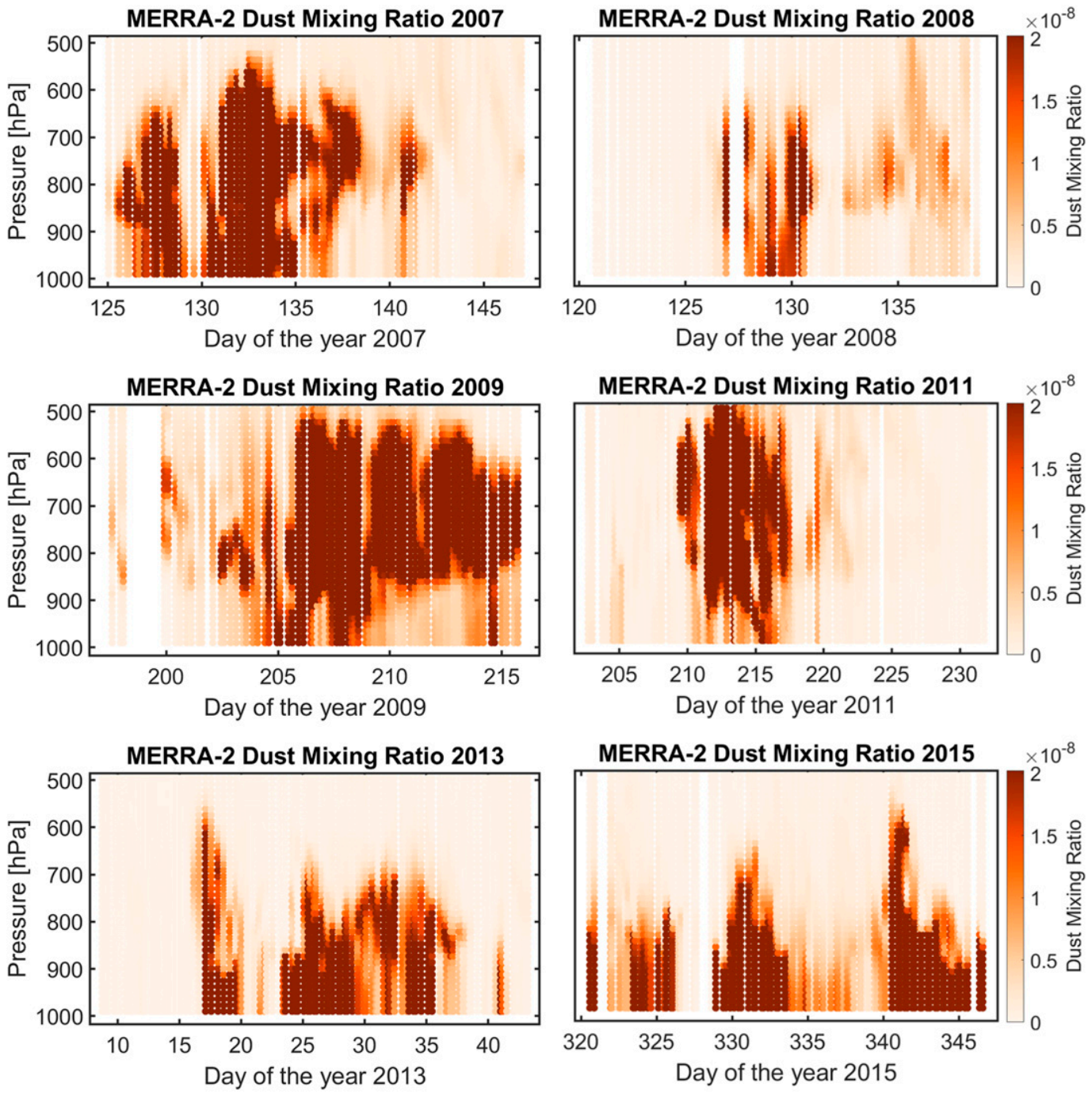

FIG. 10. MERRA-2 dust mixing ratio sections. Color indicates dust mixing ratio as shown at the right. The unit of dust mixing ratio is $\mathrm{kg} \mathrm{kg}^{-1}$.

et al. 2011; Tsamalis et al. 2013). These are areas where rainfall is often heavy and where there is intense atmospheric convection (Guidry 2006). The MERRA-2 average difference is shown in the dark lines, and the difference range is larger around $900 \mathrm{hPa}$ than for ERAInterim differences. In the southern tropical Atlantic Ocean (the yellow box in Fig. 14), the relative humidity differences range is relatively small, excepting a spike close to the surface; both MERRA-2 and ERA-Interim have large difference ranges at $820 \mathrm{hPa}$.

\section{Saharan air layer cases}

As discussed by Szczodrak et al. (2014), the spectrum of infrared emission is modified by the SAL's low humidity.
Both the MERRA-2 and ERA-Interim reanalysis clearly indicate the presence of the SAL over the subtropical Atlantic Ocean at the times of the AEROSE cruises. A comparison of individual profiles with the reanalysis fields is also performed to assess the fidelity of the reanalysis representation of elevated layers of dry air that were encountered frequently during the AEROSE cruises.

The 2011 AEROSE campaign consisted of an interhemispheric transit from the United States to South Africa. A large-scale Saharan dust outflow and smoke from biomass burning were encountered during the transit. The 2015 AEROSE cruise aboard the R/V Alliance was mainly in the Saharan dust outflow region. Two sets of selected profiles of atmospheric relative humidity from radiosonde ascents for 2011 and 2015 

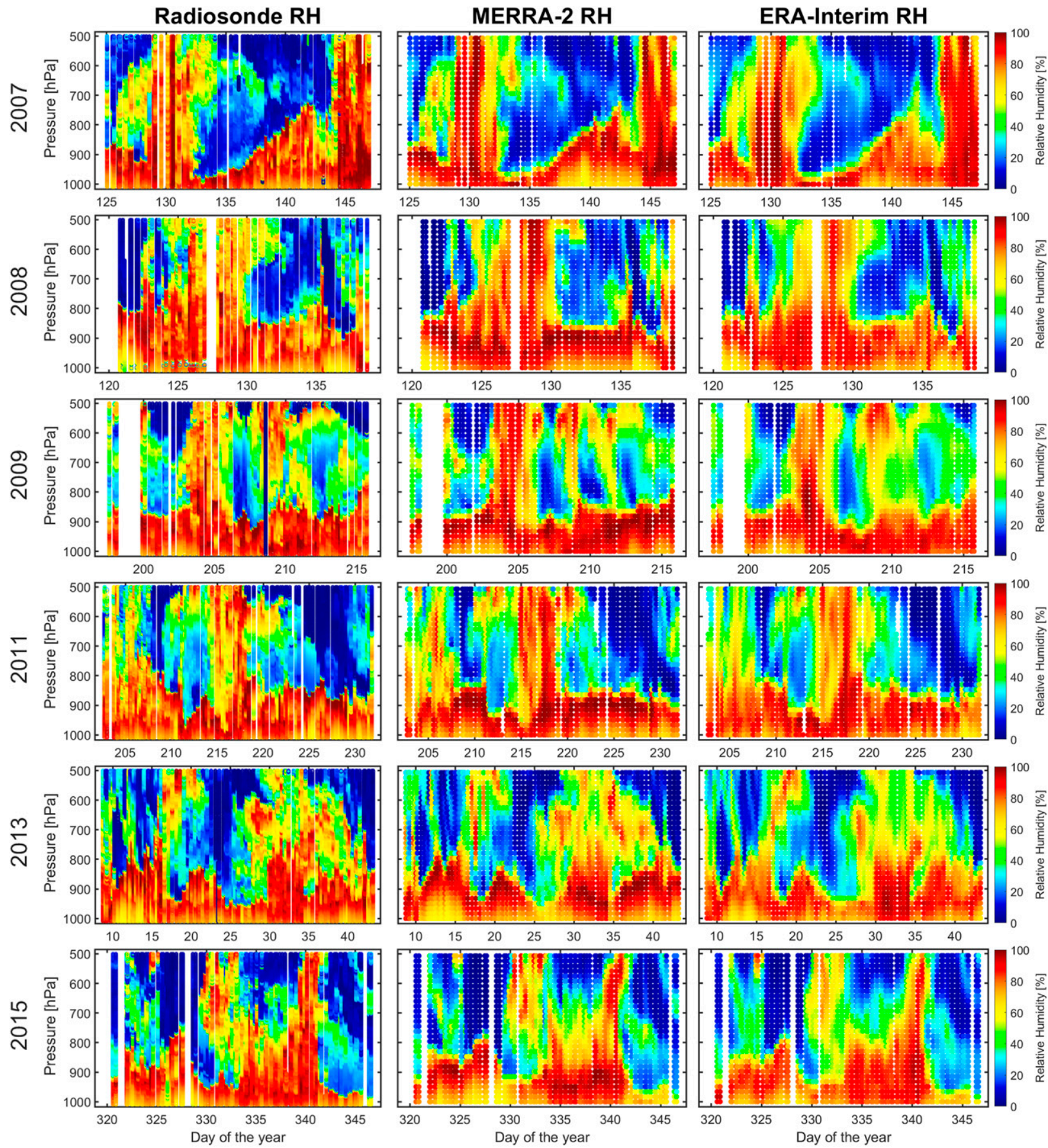

FIG. 11. Relative humidity of collocated radiosondes (left) launched from the NOAA ship Ronald H. Brown and R/V Alliance for comparison with collocated (center) MERRA-2 and (right) ERA-Interim data. Colors indicate the relative humidity according to the color bar. The dry layers are clearly visible.

(four for each year) are compared to those from MERRA-2 and ERA-Interim fields; skew $T$ - $\log p$ plots of radiosonde profiles are shown in the top parts of Figs. 15 and 16 for years 2011 and 2015. Comparisons with the reanalysis profiles are shown in the bottom panels of the two figures.
It can be seen that MERRA-2 and ERA-Interim profiles come close to the radiosonde measurements on days with strong SAL signals. Although MERRA-2 and ERAInterim typically do represent the dry layers, the vertical heights and thicknesses of the layers are not always wellmatched with those in the radiosonde profiles. While the 

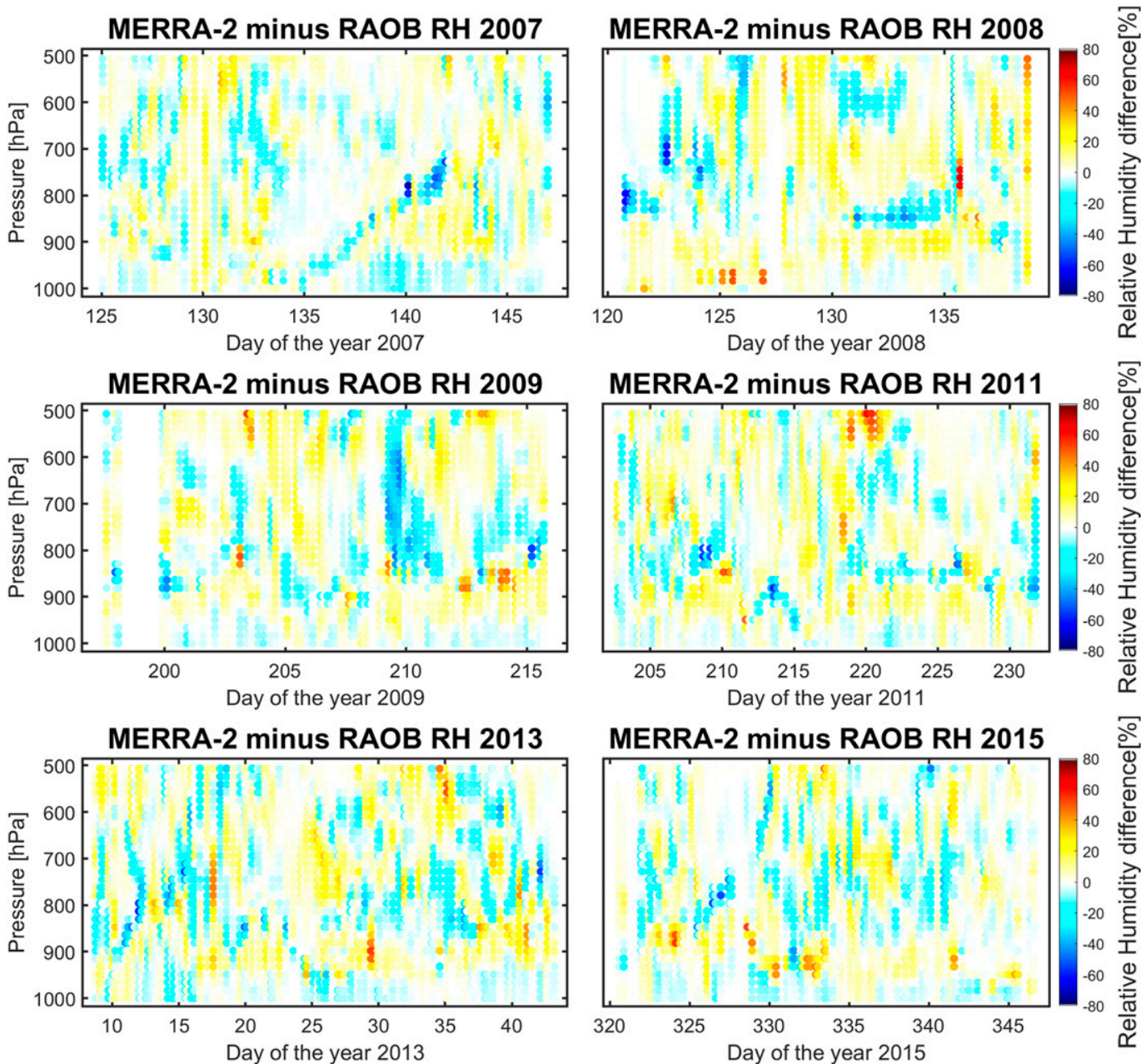

FIG. 12. Relative humidity differences between MERRA-2 data and AEROSE radiosonde (raob) measurements of each year. Color indicates relative humidity difference as shown at right.

pressures marking the bottoms of the dry layers are quite clear and there is generally good agreement between the reanalysis fields and the radiosonde measurements, the top of the layers are less well defined, and in poorer agreement. For example, on 30 July 2011 (Fig. 15), the MERRA-2 reveals the elevated dry layer top at $550 \mathrm{hPa}$, but ERA-Interim and radiosondes detect the dry layer top at $600 \mathrm{hPa}$; on 26 November 2015 (Fig. 16), the elevated dry layer top altitude in the ERA-Interim profile is $650 \mathrm{hPa}$, but it is at $700 \mathrm{hPa}$ in the MERRA-2 profile and $600 \mathrm{hPa}$ in radiosonde measurements. The vertical displacement of the dry layers in the MERRA-2 and ERAInterim profiles may lead to significant differences at higher altitudes, as discussed in sections $4 \mathrm{~b}$ and $4 \mathrm{c}$. Nevertheless, in most cases, the MERRA-2 and ERAInterim reanalysis profiles represent accurately the atmospheric relative humidity below $500 \mathrm{hPa}$, as shown in Figs. 15 and 16 . The average relative humidity differs by less than $10 \%$ depending on deployment location and vertical pressure level.

\section{Discussion and summary}

By combining various sources of observations and modeling through assimilation systems, MERRA-2 and ERA-Interim provide consistent global gridded sea surface and atmospheric data fields for scientific research. M-AERI and radiosonde data collected during AEROSE cruises provide independent marine and atmospheric reference measurements for evaluating the corresponding variables in the MERRA-2 and ERAInterim reanalysis fields. The reliability and shortcomings of the variables have been assessed here.

The $\mathrm{SST}_{\text {skin }}$ derived by M-AERI can remove the contribution to the comparisons of oceanic temperature gradients. The results of the $\mathrm{SST}_{\text {skin }}$ comparisons 

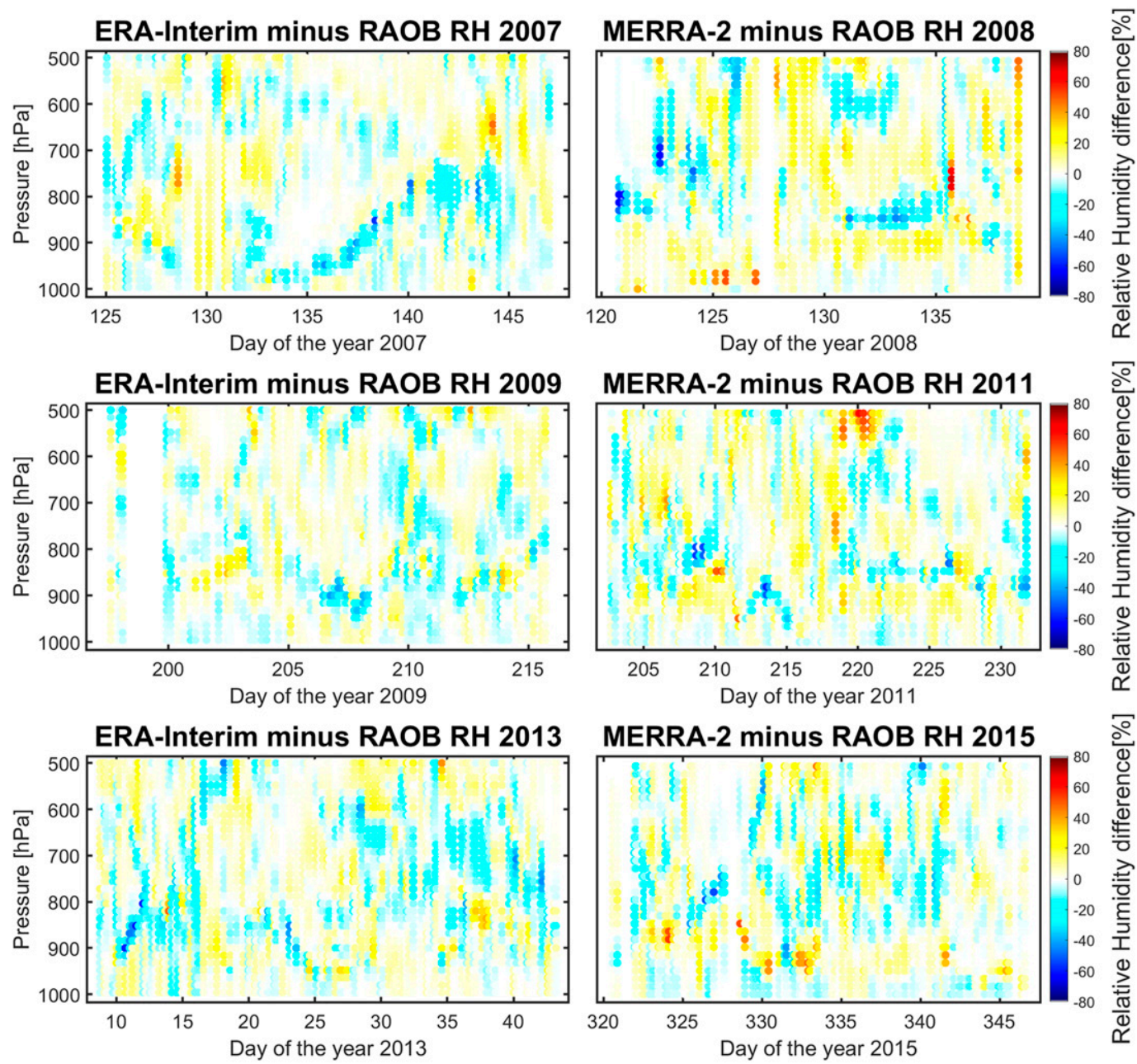

FIG. 13. As in Fig. 12, but for ERA-Interim.

indicate that the MERRA-2 and ERA-Interim reanalysis provide accurate fields in the geographic areas and conditions considered here. For the $\mathrm{SST}_{\text {skin }}$, the comparison between the reanalysis and measurements calculated from 17754 matchup points shows that the MERRA-2 $\mathrm{SST}_{\text {skin }}$ has a difference of $0.085 \mathrm{~K}$ (daytime) and $0.098 \mathrm{~K}$ (nighttime), with a STD of $\sim 0.3 \mathrm{~K}$ and RMS of $\sim 0.3 \mathrm{~K}$, with respect to M-AERI SST skin $_{\text {, while ERA- }}$ Interim has a difference of nearly $0.123 \mathrm{~K}$ (daytime) and $0.142 \mathrm{~K}$ (nighttime) with a STD of $\sim 0.4 \mathrm{~K}$ and a RMS of $\sim 0.4 \mathrm{~K}$. Negative differences are mainly localized in the Saharan dust outflow region for both reanalysis datasets, and these are likely due to aerosol contamination being inappropriately accounted for in the satellite-derived infrared $\mathrm{SST}_{\text {skin }}$ assimilated into both models used in the reanalysis.

MERRA-2 and ERA-Interim fields are not based on directly observed data above $300 \mathrm{hPa}$, and the relative humidity is not reliable in the radiosonde measurements in the presence of ice clouds of radiosondes. Consequently, only radiosonde measured air temperature and relative humidity below $500 \mathrm{hPa}$ were used in this study. The 553 radiosondes launched every $4-8 \mathrm{~h}$ during AEROSE cruises serve as the validation dataset. The dry layers associated with the Saharan dust outflow over the tropical and subtropical Atlantic are present in both MERRA-2 and ERA-Interim fields. The related MERRA-2 and ERA-Interim profiles have good accuracy: MERRA-2 and ERA-Interim data agree with radiosondes within $2 \mathrm{~K}$ in the air temperature from the surface to $500 \mathrm{hPa}$, but the MERRA-2 and ERA-Interim data show a large difference near the edges of the dust layer. Compared with MERRA-2, the ERA-Interim reanalysis profiles are somewhat closer to the radiosonde data.

A study of SAL cases was also used to evaluate the MERRA-2 and ERA-Interim accuracies under these 


\section{Locations of all Radiosonde deployment stations}
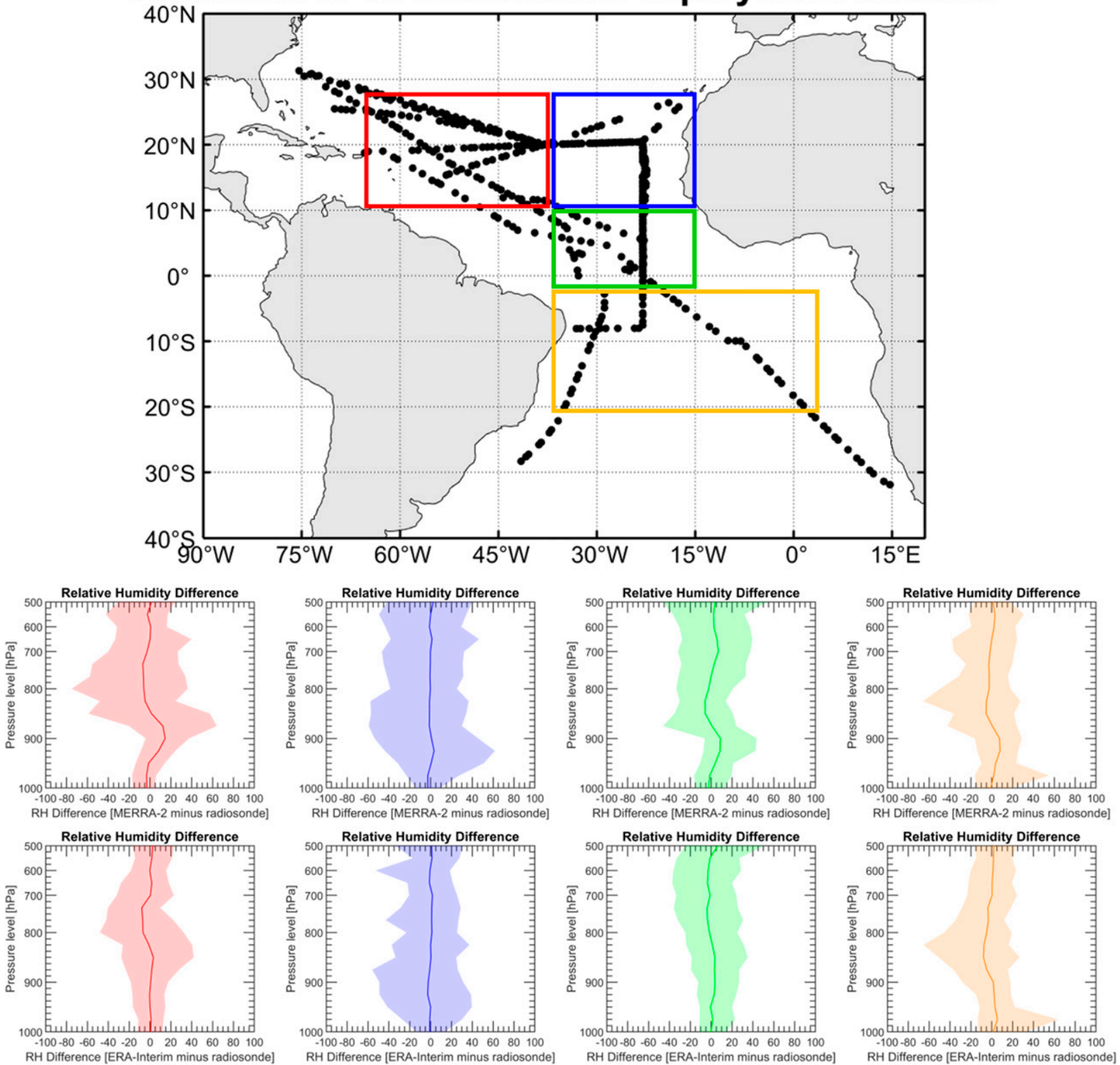

FIG. 14. (top) The tracks of the NOAA ship Ronald H. Brown in 2007-13 and R/V Alliance in 2015, in the tropical and subtropical Atlantic during AEROSE cruises. The points indicate positions of radiosonde launches. Different regions are colored according to latitude/longitude. (bottom) Vertical distribution of relative humidity differences in each area; dark lines are mean profiles, and the envelopes are the range of the differences.

conditions. Profiles in the skew-T format illustrate that both MERRA-2 and ERA-Interim capture well individual profiles of atmospheric temperature and relative humidity below $500 \mathrm{hPa}$. But the heights of the dry layers in both the MERRA-2 and ERA-Interim do not always match those of radiosonde measurements, and some of the differences may be due to different spatial and vertical resolutions of the datasets. When the data are considered in different regions of the Atlantic Ocean with different atmospheric characteristics, the computed statistics reveal differences in reanalysis profile performance in those regions. Overall, the relative humidity differences are consistent with other MERRA-2 validations, for example as reported by Kennedy et al. (2011). 

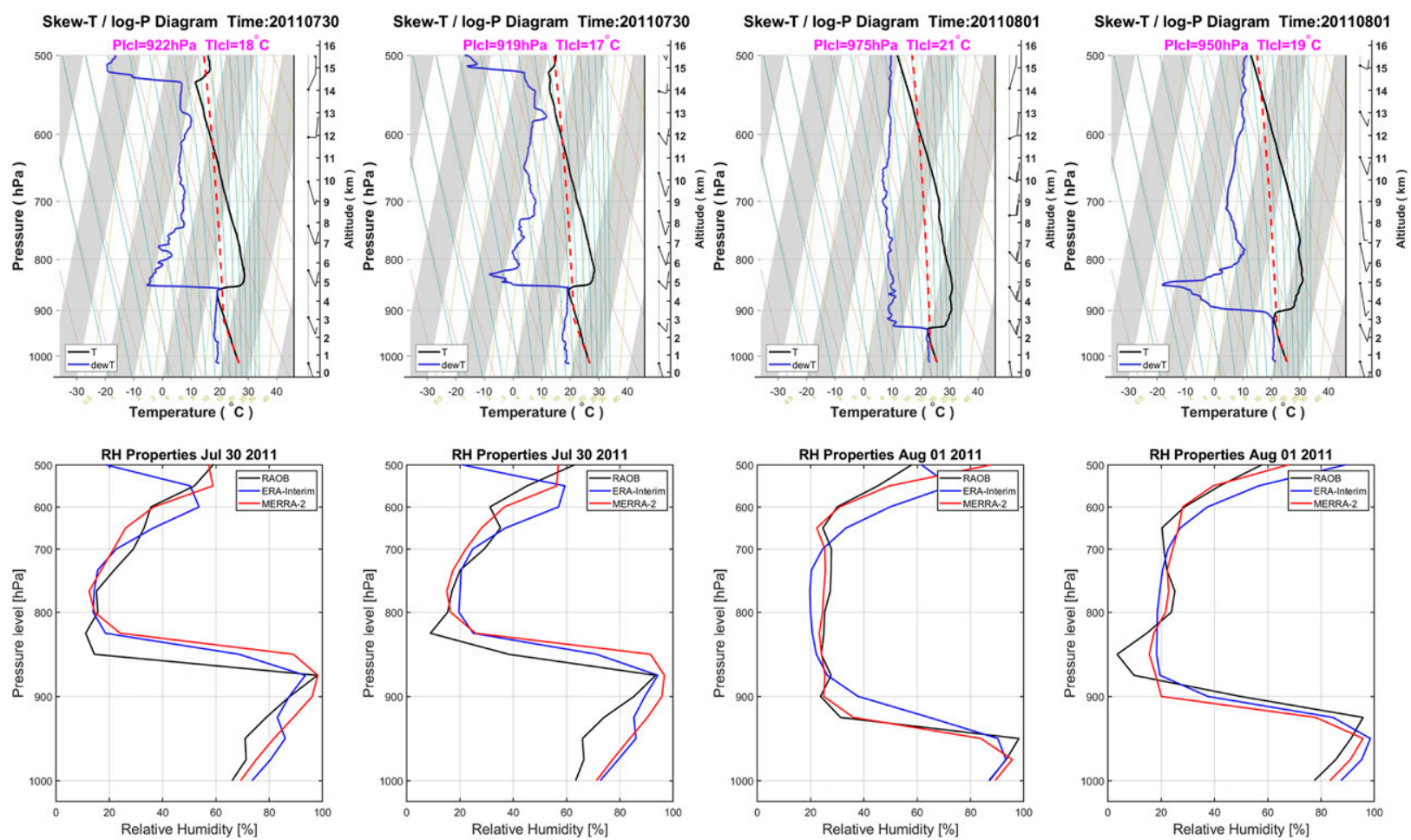

FIG. 15. (top) Skew $T$ plots of radiosondes profiles from the 2011 cruise onboard the NOAA ship Ronald H. Brown under SAL conditions on $30 \mathrm{Jul}$ and 1 Aug. (bottom) Corresponding relative humidity profiles from radiosonde, ERA-Interim, and MERRA-2. Radiosonde profiles are indicated by black lines, MERRA-2 profiles by red, and ERA-Interim by blue.

Generating climate data records of SST, relative humidity, and air temperature profiles has significant advantages in being able to combine measurements from multiple sources on decadal time scales into reanalysis products. Climate change and weather prediction studies rely on accurate knowledge of these parameters. This paper illustrates the accuracy of MERRA-2 and ERAInterim SST, relative humidity, and air temperature profiles. Broad community users seeking good-quality data with a known uncertainty are recommended to pay attention to the bias discussed by our study.

It needs to be clarified that this evaluation focused only on reanalysis $\mathrm{SST}_{\text {skin }}$, and vertical temperature and relative humidity profiles over the Atlantic region, especially in the SAL region, and should not be considered an indication of the overall global performance of MERRA-2 and ERA-Interim reanalyses. With the completion of the ERA5 analysis, longer time scales and better temporal and spatial resolution are now available (Copernicus Climate Change Service Climate Data Store 2017). With more AEROSE data recently collected, further comparison studies with independent measurements and ERA-5 data will be the subject of future work.
Acknowledgments. The field components of this research were supported in part by grants from the NASA Physical Oceanography Program (Grant NNX14AK18G) and Future Investigators in NASA Earth and Space Science and Technology (FINESST) Program (Grant 80NSSC19K1326). AEROSE works in collaboration with the NOAA PIRATA Northeast Extension (PNE) project and is supported by the NOAA Center for Atmospheric Sciences and Meteorology (NCAS-M) at Howard University, the NOAA Educational Partnership Program Grant NA17AE1625, NOAA Grant NA17AE1623, the Joint Polar Satellite System (JPSS), and NOAA/ NESDIS/STAR. Support from the Educational Partnership Program for Minority-Serving Institutions under NOAA Cooperative Agreement NA16SEC4810006 is acknowledged. MERRA-2 data were downloaded through the NASA Goddard Earth Sciences (GES) Data and Information Services Center (DISC) at http:// disc.sci.gsfc.nasa.gov/mdisc/. ERA-Interim data were downloaded through ECMWF at https://apps.ecmwf.int/ datasets/data/interim-full-daily/levtype $=\mathrm{sfc} /$. This work has benefited from discussions with colleagues at RSMAS, including Katherine A. Kilpatrick and Miguel A. Izaguirre. The at-sea support of the officers 

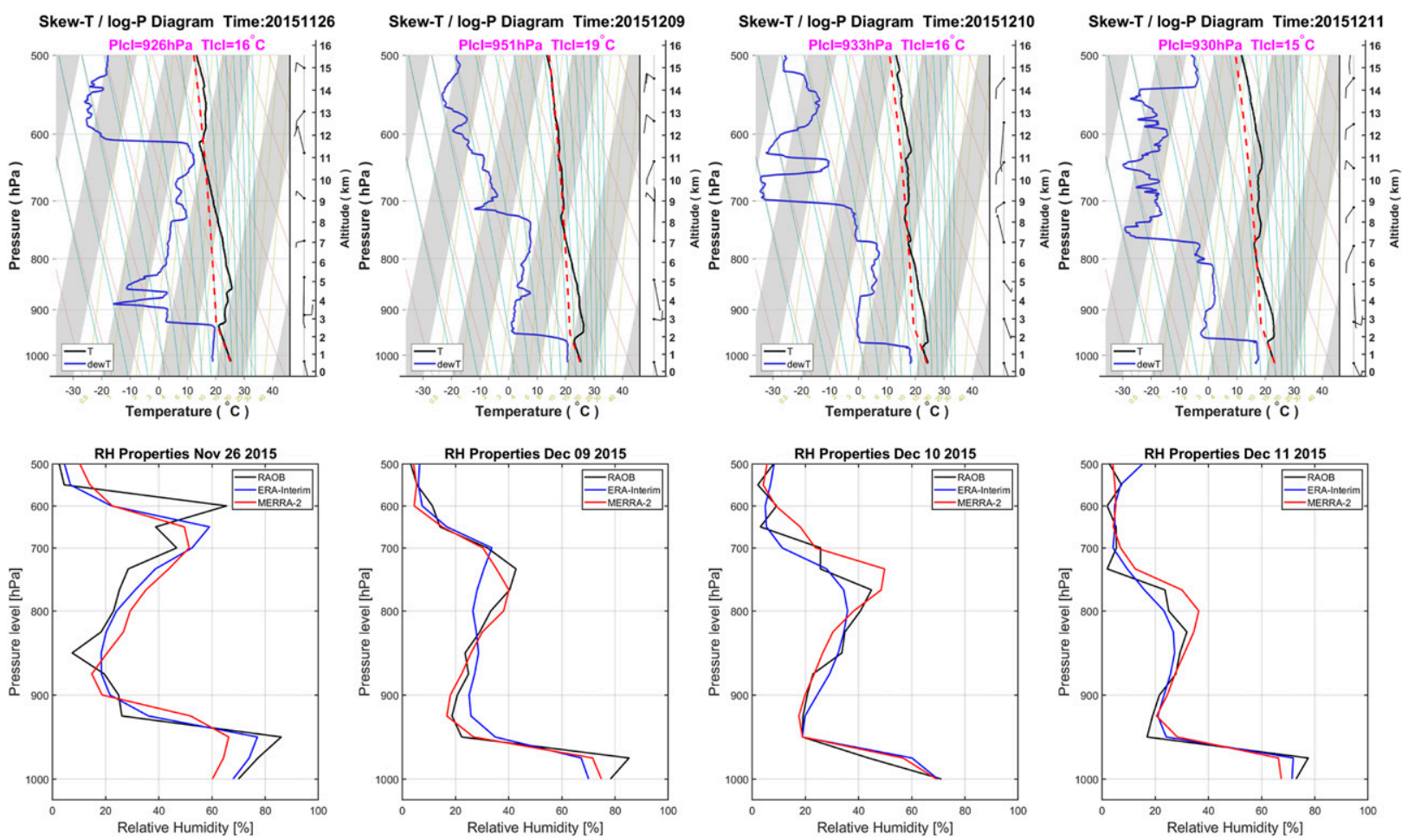

FIG. 16. As in Fig. 15, but for the R/V Alliance AEROSE cruise. Profiles are for 26 Nov and 9-11 Dec 2015.

and crew, along with many colleagues and students, onboard the NOAA Ship Ronald H. Brown and R/V Alliance is acknowledged.

\section{REFERENCES}

Adams, A. M., J. M. Prospero, and C. Zhang, 2012: CALIPSOderived three-dimensional structure of aerosol over the Atlantic basin and adjacent continents. J. Climate, 25, 68626879, https://doi.org/10.1175/JCLI-D-11-00672.1.

Akella, S., R. Todling, and M. Suarez, 2017: Assimilation for skin SST in the NASA GEOS atmospheric data assimilation system. Quart. J. Roy. Meteor. Soc., 143, 1032-1046, https:// doi.org/10.1002/qj.2988.

Aminou, D. M. A., 2002: MSG's SEVIRI instrument. ESA Bull., 111, 15-17.

Barton, I. J., 2011: Improving satellite-derived sea surface temperature accuracies using water vapor profile data. J. Atmos. Oceanic Technol., 28, 85-93, https://doi.org/10.1175/2010JTECHA1502.1.

Bosilovich, M. G., and Coauthors, 2015: MERRA-2: Initial evaluation of the climate, 145 pp., https://gmao.gsfc.nasa.gov/pubs/ docs/Bosilovich803.pdf.

—, F. R. Robertson, L. Takacs, A. Molod, and D. Mocko, 2017: Atmospheric water balance and variability in the MERRA-2 reanalysis. J. Climate, 30, 1177-1196, https://doi.org/10.1175/ JCLI-D-16-0338.1.

Bourlès, B., and Coauthors, 2019: PIRATA: A sustained observing system for tropical Atlantic climate research and forecasting. Earth Space Sci., 6, 577-616, https://doi.org/10.1029/ 2018EA000428.
Buchard, V., and Coauthors, 2017: The MERRA-2 aerosol reanalysis, 1980 onward. Part II: Evaluation and case studies. J. Climate, 30, 6851-6872, https://doi.org/10.1175/JCLI-D-160613.1.

Caponi, L., and Coauthors, 2017: Spectral- and size-resolved mass absorption efficiency of mineral dust aerosols in the shortwave spectrum: A simulation chamber study. Atmos. Chem. Phys., 17, 7175-7191, https://doi.org/10.5194/acp-17-7175-2017.

Clark, H., and R. Harwood, 2003: Upper-tropospheric humidity from MLS and ECMWF reanalyses. Mon. Wea. Rev., 131, 542-555, https://doi.org/10.1175/1520-0493(2003)131<0542: UTHFMA $>2.0 . \mathrm{CO} ; 2$.

Copernicus Climate Change Service Climate Data Store, 2017: ERA5: Fifth generation of ECMWF atmospheric reanalyses of the global climate. Copernicus Climate Change Service (C3S), accessed 1 December 2019, https://cds.climate.copernicus.eu/ cdsapp\#!/dataset/reanalysis-era5-single-levels?tab=overview.

Courtier, P., J.-N. Thépaut, and A. Hollingsworth, 1994: A strategy for operational implementation of 4D-Var, using an incremental approach. Quart. J. Roy. Meteor. Soc., 120,1367-1387, https://doi.org/10.1002/qj.49712051912.

Dee, D. P., and Coauthors, 2011: The ERA-Interim reanalysis: Configuration and performance of the data assimilation system. Quart. J. Roy. Meteor. Soc., 137, 553-597, https://doi.org/ 10.1002/qj.828.

Dirksen, R., M. Sommer, F. Immler, D. Hurst, R. Kivi, and H. Vömel, 2014: Reference quality upper-air measurements: GRUAN data processing for the Vaisala RS92 radiosonde. Atmos. Meas. Tech., 7, 4463-4490, https://doi.org/10.5194/amt-7-4463-2014.

Divakarla, M. G., C. D. Barnet, M. D. Goldberg, L. M. McMillin, E. Maddy, W. Wolf, L. Zhou, and X. Liu, 2006: Validation of Atmospheric Infrared Sounder temperature and water vapor 
retrievals with matched radiosonde measurements and forecasts. J. Geophys. Res., 111, D09S15, https://doi.org/10.1029/ 2005jd006116.

Donlon, C., and Coauthors, 2007: The Global Ocean Data Assimilation Experiment High-Resolution Sea Surface Temperature Pilot Project. Bull. Amer. Meteor. Soc., 88, 11971214, https://doi.org/10.1175/BAMS-88-8-1197.

, and Coauthors, 2012: The Global Monitoring for Environment and Security (GMES) Sentinel-3 mission. Remote Sens. Environ., 120, 37-57, https://doi.org/10.1016/ j.rse.2011.07.024.

ECMWF, 2016: Part IV: Physical processes. IFS Documentation CY43R1, ECMWF Doc., 223 pp., https://www.ecmwf.int/ node/17117.

Fairall, C., E. Bradley, J. Godfrey, G. Wick, J. Edson, and G. Young, 1996: Cool-skin and warm-layer effects on sea surface temperature. J. Geophys. Res., 101, 1295-1308, https:// doi.org/10.1029/95JC03190.

Foltz, G. R., C. Schmid, and R. Lumpkin, 2018: An enhanced PIRATA dataset for tropical Atlantic Ocean-atmosphere research. J. Climate, 31, 1499-1524, https://doi.org/10.1175/ JCLI-D-16-0816.1.

Forster, P., and Coauthors, 2007: Changes in atmospheric constituents and in radiative forcing. Climate Change 2007: The Physical Science Basis, S. Solomon et al., Eds., Cambridge University Press, 129-234.

Gehlot, S., P. J. Minnett, and D. Stammer, 2015: Impact of Sahara dust on solar radiation at Cape Verde Islands derived from MODIS and surface measurements. Remote Sens. Environ., 166, 154-162, https://doi.org/10.1016/j.rse.2015.05.026.

Gelaro, R., and Coauthors, 2017: The Modern-Era Retrospective Analysis for Research and Applications, version 2 (MERRA2). J. Climate, 30, 5419-5454, https://doi.org/10.1175/JCLI-D16-0758.1.

Gentemann, C. L., C. J. Donlon, A. Stuart-Menteth, and F. J. Wentz, 2003: Diurnal signals in satellite sea surface temperature measurements. Geophys. Res. Lett., 30, 1140-1143, https://doi.org/10.1029/2002GL016291.

Guan, B., D. E. Waliser, and F. M. Ralph, 2018: An intercomparison between reanalysis and dropsonde observations of the total water vapor transport in individual atmospheric rivers. J. Hydrometeor., 19, 321-337, https://doi.org/10.1175/JHM-D17-0114.1.

Guidry, M. W., 2006: Climate and water resource case study: Chapter 4-C, Intertropical convergence zone. SOEST, accessed 1 December 2019, http://www.soest.hawaii.edu/mguidry/ Unnamed_Site_2/Chapter\%204/Chapter4C.html.

Han, Y., and Coauthors, 2013: Suomi NPP CrIS measurements, sensor data record algorithm, calibration and validation activities, and record data quality. J. Geophys. Res. Atmos., 118, 12 734-12 748, https://doi.org/10.1002/2013JD020344.

Hartmann, D. L., 2002: Climate change, tropical surprises. Science, 295, 811-812, https://doi.org/10.1126/science.1068447.

Hyland, R., and A. Wexter, 1983: Formulations for the thermodynamic properties of the saturated phases of $\mathrm{H}_{2} \mathrm{O}$ from $173.15 \mathrm{~K}$ to $473.15 \mathrm{~K}$. ASHRAE Trans., 89, 500-519.

Jordan, N. S., R. M. Hoff, and J. T. Bacmeister, 2010: Validation of Goddard Earth Observing System-version 5 MERRA planetary boundary layer heights using CALIPSO. J. Geophys. Res., 115, D24218, http://doi.org/10.1029/2009JD013777.

Kalnay, E., and Coauthors, 1996: The NCEP/NCAR 40-Year Reanalysis Project. Bull. Amer. Meteor. Soc., 77, 437-471, https:// doi.org/10.1175/1520-0477(1996)077<0437:TNYRP>2.0.CO;2.
Kanitz, T., R. Engelmann, B. Heinold, H. Baars, A. Skupin, and A. Ansmann, 2014: Tracking the Saharan air layer with shipborne lidar across the tropical Atlantic. Geophys. Res. Lett., 41, 1044-1050, https://doi.org/10.1002/2013GL058780.

Kaufman, Y. J., D. Tanré, and O. Boucher, 2002: A satellite view of aerosols in the climate system. Nature, 419, 215-223, https:// doi.org/10.1038/nature01091.

Kennedy, A. D., X. Dong, B. Xi, S. Xie, Y. Zhang, and J. Chen, 2011: A comparison of MERRA and NARR reanalyses with the DOE ARM SGP data. J. Climate, 24, 4541-4557, https:// doi.org/10.1175/2011JCLI3978.1.

Kim, E., C. H. J. Lyu, K. Anderson, R. V. Leslie, and W. J. Blackwell, 2014: S-NPP ATMS instrument prelaunch and onorbit performance evaluation. J. Geophys. Res., 119, 56535670, https://doi.org/10.1002/2013JD020483.

Kobayashi, S., and Coauthors, 2015: The JRA-55 reanalysis: General specifications and basic characteristics. J. Meteor. Soc. Japan, 93, 5-48, https://doi.org/10.2151/JMSJ.2015-001.

Luo, B., and P. J. Minnett, 2020: Evaluation of the ERA5 sea surface skin temperature with remotely-sensed shipborne marine-atmospheric emitted radiance interferometer data. Remote Sens., 12, 1873, https://doi.org/10.3390/rs12111873.

,$- \ldots$, C. Gentemann, and G. Szczodrak, 2019: Improving satellite retrieved night-time infrared sea surface temperatures in aerosol contaminated regions. Remote Sens. Environ., 223, 8-20, https://doi.org/10.1016/j.rse.2019.01.009.

,,-- M. Szczodrak, K. Kilpatrick, and M. Izaguirre, 2020: Validation of Sentinel-3A SLSTR derived sea-surface skin temperatures with those of the shipborne M-AERI. Remote Sens. Environ., 244, 111826, https://doi.org/10.1016/j.rse.2020. 111826.

Marticorena, B., J. Haywood, H. Coe, P. Formenti, C. Liousse, M. Mallet, and J. Pelon, 2011: Tropospheric aerosols over West Africa: Highlights from the AMMA international program. Atmos. Sci. Lett., 12, 19-23, https://doi.org/10.1002/asl.322.

McCarty, W., L. Coy, R. Gelaro, A. Huang, D. Merkova, E. B. Smith, M. Sienkiewicz, and K. Wargan, 2016: MERRA-2 input observations: Summary and initial assessment. Technical Report Series on Global Modeling and Data Assimilation, Vol. 46, NASA Tech. Rep. NASA/TM-2016-104606, 61 pp., https://gmao.gsfc.nasa.gov/pubs/docs/McCarty885.pdf.

McGrath, R., T. Semmler, C. Sweeney, and S. J. J. Wang, 2006: Impact of balloon drift errors in radiosonde data on climate statistics. J. Climate, 19, 3430-3442, https://doi.org/10.1175/ JCLI3804.1.

Miloshevich, L. M., A. Paukkunen, H. Vömel, and S. J. Oltmans, 2004: Development and validation of a time-lag correction for Vaisala radiosonde humidity measurements. J. Atmos. Oceanic Technol., 21, 1305-1327, https://doi.org/10.1175/1520-0426(2004) 021<1305:DAVOAT >2.0.CO;2.

- H. Vömel, D. N. Whiteman, B. M. Lesht, F. Schmidlin, and F. Russo, 2006: Absolute accuracy of water vapor measurements from six operational radiosonde types launched during AWEX-G and implications for AIRS validation. J. Geophys. Res., 111, D09S10, https://doi.org/10.1029/2005jd006083.

Minnett, P. J., 1986: A numerical study of the effects of anomalous North Atlantic atmospheric conditions on the infrared measurement of sea-surface temperature from space. J. Geophys. Res., 91, 8509-8521, https://doi.org/10.1029/JC091iC07p08509. , 2003: Radiometric measurements of the sea-surface skin temperature-The competing roles of the diurnal thermocline and the cool skin. Int. J. Remote Sens., 24, 5033-5047, https:// doi.org/10.1080/0143116031000095880. 
R. O. Knuteson, F. A. Best, B. J. Osborne, J. A. Hanafin, and O. B. Brown, 2001: The Marine-Atmospheric Emitted Radiance Interferometer (M-AERI), a high-accuracy, sea-going infrared spectroradiometer. J. Atmos. Oceanic Technol., 18, 994-1013, https://doi.org/10.1175/1520-0426(2001)018<0994:TMAERI > 2.0.CO;2.

Morris, V., and Coauthors, 2006: Measuring trans-Atlantic aerosol transport from Africa. Eos, Trans. Amer. Geophys. Union, 87, 565-571, https://doi.org/10.1029/2006EO500001.

Nalli, N. R., and L. L. Stowe, 2002: Aerosol correction for remotely sensed sea surface temperatures from the National Oceanic and Atmospheric Administration Advanced Very High Resolution Radiometer. J. Geophys. Res., 107, 3172, https:// doi.org/10.1029/2001jc001162.

_ - and Coauthors, 2006: Ship-based measurements for infrared sensor validation during Aerosol and Ocean Science Expedition 2004. J. Geophys. Res., 111, D09S04, https:// doi.org/10.1029/2005JD006385.

—_, and Coauthors, 2011: Multiyear observations of the tropical Atlantic atmosphere: Multidisciplinary applications of the NOAA aerosols and ocean science expeditions. Bull. Amer. Meteor. Soc., 92, 765-789, https://doi.org/10.1175/ 2011BAMS2997.1.

_ , and Coauthors, 2013: Validation of satellite sounder environmental data records: Application to the cross-track infrared microwave sounder suite. J. Geophys. Res. Atmos., 118, 13 628-13 643, https://doi.org/10.1002/2013JD020436.

— - W. L. Smith, and Q. Liu, 2016: Angular effect of undetected clouds in infrared window radiance observations: Aircraft experimental analyses. J. Atmos. Sci., 73, 1987-2010, https:// doi.org/10.1175/JAS-D-15-0262.1.

Parker, W. S., 2016: Reanalyses and observations: What's the difference? Bull. Amer. Meteor. Soc., 97, 1565-1572, https:// doi.org/10.1175/BAMS-D-14-00226.1.

Pergaud, J., V. Masson, S. Malardel, and F. Couvreux, 2009: A parameterization of dry thermals and shallow cumuli for mesoscale numerical weather prediction. Bound.-Layer Meteor., 132, 83-106, https://doi.org/10.1007/s10546-009-9388-0.

Randles, C. A., and Coauthors, 2017: The MERRA-2 aerosol reanalysis, 1980 onward. Part I: System description and data assimilation evaluation. J. Climate, 30, 6823-6850, https:// doi.org/10.1175/JCLI-D-16-0609.1.

Reynolds, R. W., T. M. Smith, C. Liu, D. B. Chelton, K. S. Casey, and M. G. Schlax, 2007: Daily high-resolution-blended analyses for sea surface temperature. J. Climate, 20, 5473-5496, https://doi.org/10.1175/2007JCLI1824.1.

Rienecker, M. M., and Coauthors, 2011: MERRA: NASA's Modern-Era Retrospective Analysis for Research and Applications. J. Climate, 24, 3624-3648, https://doi.org/ 10.1175/JCLI-D-11-00015.1.

Robertson, F. R., M. G. Bosilovich, and J. B. Roberts, 2016: Reconciling land-ocean moisture transport variability in reanalyses with $P-$ ET in observationally driven land surface models. J. Climate, 29, 8625-8646, https://doi.org/10.1175/JCLI-D-16-0379.1.

Saha, S., and Coauthors, 2014: The NCEP Climate Forecast System version 2. J. Climate, 27, 2185-2208, https://doi.org/10.1175/ JCLI-D-12-00823.1.

Simmons, A. J., A. Untch, C. Jakob, P. Kållberg, and P. Unden, 1999: Stratospheric water vapour and tropical tropopause temperatures in ECMWF analyses and multi-year simulations.
Quart. J. Roy. Meteor. Soc., 125, 353-386, https://doi.org/ 10.1002/qj.49712555318.

, P. Poli, D. P. Dee, P. Berrisford, H. Hersbach, S. Kobayashi, and C. Peubey, 2014: Estimating low-frequency variability and trends in atmospheric temperature using ERA-Interim. Quart. J. Roy. Meteor. Soc., 140, 329-353, https://doi.org/ 10.1002/qj.2317.

Szczodrak, M., P. J. Minnett, N. R. Nalli, and W. F. Feltz, 2007: Profiling the lower troposphere over the ocean with infrared hyperspectral measurements of the Marine-Atmosphere Emitted Radiance Interferometer. J. Atmos. Oceanic Technol., 24, 390-402, https://doi.org/10.1175/JTECH1961.1.

,-- , and R. H. Evans, 2014: The effects of anomalous atmospheres on the accuracy of infrared sea-surface temperature retrievals: Dry air layer intrusions over the tropical ocean. Remote Sens. Environ., 140, 450-465, https://doi.org/10.1016/ j.rse.2013.09.010.

Takacs, L. L., M. J. Suárez, and R. Todling, 2016: Maintaining atmospheric mass and water balance in reanalyses. Quart. J. Roy. Meteor. Soc., 142, 1565-1573, https://doi.org/10.1002/ qj. 2763 .

Taylor, K. E., D. Williamson, and F. Zwiers, 2000: The sea surface temperature and sea-ice concentration boundary conditions for AMIP II simulations. Program for Climate Model Diagnosis and Intercomparison Rep. 60, Lawrence Livermore National Laboratory, University of California, 20 pp., http:// www-pcmdi.llnl.gov/internal/pcmdi/pubs/ab60.html.

Tsamalis, C., A. Chédin, J. Pelon, and V. Capelle, 2013: The seasonal vertical distribution of the Saharan Air Layer and its modulation by the wind. Atmos. Chem. Phys., 13, 1123511257, https://doi.org/10.5194/acp-13-11235-2013.

Vergados, P., A. J. Mannucci, and C. O. Ao, 2014: Assessing the performance of GPS radio occultation measurements in retrieving tropospheric humidity in cloudiness: A comparison study with radiosondes, ERA-Interim, and AIRS data sets. J. Geophys. Res. Atmos., 119, 7718-7731, https://doi.org/ 10.1002/2013JD021398.

Vömel, H., and Coauthors, 2007: Radiation dry bias of the Vaisala RS92 humidity sensor. J. Atmos. Oceanic Technol., 24, 953963, https://doi.org/10.1175/JTECH2019.1.

Weckwerth, T. M., V. Wulfmeyer, R. M. Wakimoto, R. M. Hardesty, J. W. Wilson, and R. M. Banta, 1999: NCARNOAA lower-tropospheric water vapor workshop. Bull. Amer. Meteor. Soc., 80, 2339-2357, https://doi.org/10.1175/ 1520-0477(1999)080<2339:NNLTWV>2.0.CO;2.

Wexler, A., 1976: Vapor pressure formulation for water in range $0^{\circ}$ to $100^{\circ} \mathrm{C}-\mathrm{A}$ revision. J. Res. Natl. Bur. Stand., 80A, 775-785, https://doi.org/10.6028/JRES.080A.071.

Wong, E. W., and P. J. Minnett, 2018: The response of the ocean thermal skin layer to variations in incident infrared radiation. J. Geophys. Res. Oceans, 123, 2475-2493, https://doi.org/ 10.1002/2017JC013351.

Woodcock, A. H., and H. Stommel, 1947: Temperatures observed near the surface of a fresh water pond at night. J. Meteor., 4, 102-103, https://doi.org/10.1175/1520-0469(1947)004<0102: TONTSO $>2.0 . \mathrm{CO} ; 2$.

Zeng, X., and A. Beljaars, 2005: A prognostic scheme of sea surface skin temperature for modeling and data assimilation. Geophys. Res. Lett., 32, L14605, https://doi.org/10.1029/2005GL023030. 